\title{
Metabolic and enzymatic changes associated with carbon mobilization, utilization and replenishment triggered in grain amaranth (Amaranthus cruentus) in response to partial defoliation by mechanical injury or insect herbivory
}

Paula Andrea Castrillón-Arbeláez¹, Norma Martínez-Gallardo', Hamlet Avilés Arnaut ², Axel Tiessen and John Paul Délano-Frier ${ }^{1 *}$

\begin{abstract}
Background: Amaranthus cruentus and A. hypochondriacus are crop plants grown for grain production in subtropical countries. Recently, the generation of large-scale transcriptomic data opened the possibility to study representative genes of primary metabolism to gain a better understanding of the biochemical mechanisms underlying tolerance to defoliation in these species. A multi-level approach was followed involving gene expression analysis, enzyme activity and metabolite measurements.

Results: Defoliation by insect herbivory (HD) or mechanical damage (MD) led to a rapid and transient reduction of non-structural carbohydrates (NSC) in all tissues examined. This correlated with a short-term induction of foliar sucrolytic activity, differential gene expression of a vacuolar invertase and its inhibitor, and induction of a sucrose transporter gene. Leaf starch in defoliated plants correlated negatively with amylolytic activity and expression of a $\beta$-amylase-1 gene and positively with a soluble starch synthase gene. Fatty-acid accumulation in roots coincided with a high expression of a phosphoenolpyruvate/phosphate transporter gene. In all tissues there was a long-term replenishment of most metabolite pools, which allowed damaged plants to maintain unaltered growth and grain yield. Promoter analysis of ADP-glucose pyrophosphorylase and vacuolar invertase genes indicated the presence of cis-regulatory elements that supported their responsiveness to defoliation. HD and MD had differential effects on transcripts, enzyme activities and metabolites. However, the correlation between transcript abundance and enzymatic activities was very limited. A better correlation was found between enzymes, metabolite levels and growth and reproductive parameters.

(Continued on next page)
\end{abstract}

\footnotetext{
* Correspondence: jdelano@ira.cinvestav.mx

'Unidad de Biotecnología e Ingeniería Genética de Plantas

(Cinvestav-Irapuato), Km 9.6 del Libramiento Norte Carretera Irapuato-León,

Apartado Postal 629, C.P. 36821 Irapuato, Gto, México

Full list of author information is available at the end of the article
} 
(Continued from previous page)

Conclusions: It is concluded that a rapid reduction of NSC reserves in leaves, stems and roots followed by their long-term recovery underlies tolerance to defoliation in grain amaranth. This requires the coordinate action of genes/enzymes that are differentially affected by the way leaf damage is performed. Defoliation tolerance in grain is a complex process that can't be fully explained at the transcriptomic level only.

Keywords: Carbohydrate metabolism, Carbohydrate mobilization, Carbon sequestration, Defoliation, Grain amaranth, Plasticity, Tolerance

\section{Background}

The genus Amaranthus is comprised by more than 60 species. It belongs to the Amaranthaceae family that also includes sugar beet, spinach, Chenopodium spp. and several halophytes [1]. They are $\mathrm{C}_{4}$ dicotyledonous annual plants, many of which are ubiquitous weeds (e.g. A. spinosus, $A$. tuberculatus and $A$. retroflexus), whereas others (e.g. A. tricolor and A. hybridus), are used as foliar vegetables of high vitamin and mineral content, mainly in Asia and Africa [2,3]. They may be also a source of grain (mostly A. caudatus, A. cruentus and A. hypochondriacus). The latter are pseudo-cereals capable of producing seeds of high nutritive and nutraceutical value, granted by their optimal amino-acid balance, potential to release bioactive peptides upon digestion and relatively high squalene levels $[3,4]$. They are hardy plants with the ability to grow in poor soils or under unfavorable growing conditions, mostly involving low water availability, high salinity and/or high light intensity $[3,5,6]$.

Vegetable and grain Amaranthus species have been reported to sustain high rates of infestation by herbivorous insects under field conditions, with differing effects on productivity $[7,8]$. Tolerance to defoliation in $A$. hybridus was associated with a greater investment in below-ground biomass relative to above-ground vegetative biomass, occurring mostly as the result of preflowering allocation of carbohydrates (CHOs) and nitrogen resources to the taproot $[9,10]$. Vegetable amaranths have been shown to recover exceptionally well from herbivore damage by grasshoppers and lepidopteran larvae [11]. However, certain insect pests can significantly reduce grain yield and increase the risk of lodging and infection by root and stem fungal pathogens [12-14]. Defoliation of grain amaranths by lepidopteran larvae at an early developmental stage has also been found to result in a long-term reduction in plant size and yield $[2,15,16]$. Insect infestation was more deleterious under drought-stress conditions [8]. Controlled experiments indicate that several Amaranthus species can fully recover from complete mechanical defoliation with small to negligible effects on fitness and yield (Vargas-Ortiz E, unpublished data). Moreover, mechanical removal of 10 -to-40\% of the primary shoot of grain amaranth plants is practiced in certain regions of Mexico to enhance secondary branching and biomass productivity [17].

Plants can respond to injury, including defoliation, by the deployment of a plethora of direct and/or indirect defenses [18,19]. However, when defenses are costly to produce or the resource demands for defense compete with those of growth and reproduction, damaged plants may undergo physiological changes such as the activation of dormant meristems, modified plant architecture, increased photosynthetic capacity, and/or the partitioning of resources among growth, storage, and reproduction, among others, in order to cope with the stress imposed by defoliation [20-22].

Source-sink relationship and carbon allocation in plants are regulated by complex metabolic and signaling networks [23]. Carbon levels in storage organs influence the net photosynthetic activity in source tissues, whereas the expression of photosynthesis-related enzymes in leaves is modified by sugar levels [24-26]. However, the mechanisms whereby sugars act to regulate source gene expression in $\mathrm{C}_{4}$ plants remain relatively unexamined [27].

Previous studies have focused on the defoliation responses of grain amaranth mostly in an ecological context. Here, we performed a more comprehensive study, involving a multifaceted approach, including genomic, promoter, gene expression and metabolite analyses in addition to enzyme activity assays. Two different defoliation treatments, insect herbivory (HD) and mechanical damage (MD), were tested considering that the responses to artificial defoliation can differ qualitatively and/or quantitatively from those produced by natural herbivory [see above; also [28,29]. The available genomic information of Amaranthus hypochondriacus (Ah) [30] was employed as a basis for gene selection and subsequent design of specific primers for real time PCR analysis and to isolate and characterize key genes involved in non-structural carbohydrate (NSC) metabolism. Gene expression at different times was studied in both sink and source tissues of damaged and control plants. The response depended strongly on the way defoliation was performed, as herbivory damage generally led to more intense changes in expression. The levels of many transcripts, enzymes and metabolites (hexoses, sucrose, starch and fatty acids) changed as a result of defoliation 
(e.g. short term decrease followed by a long-term recovery), thereby suggesting that tolerance to defoliation in amaranth might depend on the regulated use of NSC reserves controlled by key metabolic enzymes/genes. Thus, candidate grain amaranth genes known to influence $C$ allocation and sink-source relationships in other plant models were analyzed in detail and some of them were cloned. However, the relationships between transcripts and enzymes were not always as straightforward as desired.

\section{Results and discussion}

\section{Selection and cloning of Amaranth genes}

Previous knowledge of primary metabolism and stress tolerance in other model species, and preliminary expression data in amaranth directed the selection a total of 25 genes. For a more detailed description see Additional file 1. In addition, seven cDNAs and two genomic sequences of key genes involved in carbon (C) partitioning were characterized (Tables 1 and 2). Two of the seven sucrose synthase $(\mathrm{SuS})$ isoforms detected in the transcriptomic analysis [30] were chosen for further analysis. The phylogenetic analysis (Additional file 2) showed that AhSuS-1 and AhSuS-2 were highly homologous to the SBSS1-2 isoforms present in Beta vulgaris. These have been shown to be regulated by development and by several types of stress [31]. Plant invertases conform another multigenic family importantly involved in carbohydrate $(\mathrm{CHO})$ mobilization. In grain amaranth, this family is represented by at least 19 isoforms. Two isoforms belonging to the alkaline neutral invertase subfamily, AhA/NI1-2, were selected for further study taking into account their similarity to invertases that are localized to the chloroplast; in wheat and Arabidopsis, their activity has been shown to be up-regulated by environmental stresses [32,33]. On the

Table 1 cDNAs and predicted proteins of selected grain amaranth genes involved in sucrose and starch metabolism

\begin{tabular}{|c|c|c|c|c|c|c|c|c|}
\hline Gene & $\begin{array}{l}\mathrm{ORF}^{1} \\
(\mathrm{bp})^{2}\end{array}$ & $\begin{array}{l}\text { Size } \\
(b p)^{3}\end{array}$ & $\begin{array}{l}\text { Size } \\
\text { (KDa) }\end{array}$ & $\begin{array}{l}\text { Identity } \\
(\%)\end{array}$ & Species & $\begin{array}{l}\text { Accesion } \\
\text { number }\end{array}$ & Salient characteristics & Ref $^{4}$ \\
\hline AhAGPS-1 & 1524 & 2019 & 55.7 & 91 & Beta vulgaris & HM021763 & $\begin{array}{l}\text { The only small subunit AGPase detected in the Ah's } \\
\text { transcriptome. Highly similar to AGPase isoforms of } \\
\text { sugar beet root and orange fruit (Citrus sinensis). }\end{array}$ & {$[46]$} \\
\hline AhSuS-1 & 2412 & 2769 & 92.1 & 93 & Beta vulgaris & JQ012918 & $\begin{array}{l}\text { Member of a small multi-gene family of at least seven } \\
\text { different isoforms; similar to SBSS2 and CSS1 proteins } \\
\text { identified in roots of B. vulgaris and in C. rubrum, } \\
\text { respectively. Classified within the Dicot SUS-1group. }\end{array}$ & {$[47-50]$} \\
\hline AhSuS-2 & 2436 & 2832 & 93.3 & 78 & Beta vulgaris & JQ012919 & $\begin{array}{l}\text { Similar to the SBSS1 protein induced by wounding, } \\
\text { anoxia and cold-exposure in roots of B. vulgaris. Its } \\
\text { putative mitochondrial localization implies novel roles } \\
\text { apart from sucrose degradation. Classified within the } \\
\text { Dicot SUS-A group. }\end{array}$ & {$[31,50-52]$} \\
\hline$A h A / N I-1$ & 1671 & 1928 & 63.3 & 74 & Daucus carota & JQ012920 & $\begin{array}{l}\text { An A/N invertase isoform predicted to be localized to } \\
\text { the chloroplast (sub-clade } \beta \text { ). Supports the general } \\
\text { participation of A/NIs in the carbon flux between } \\
\text { the cytosol and the plastids. }\end{array}$ & {$[53,54]$} \\
\hline$A h A / N I-2^{*}$ & 903 & 1171 & 一一一 & 77 & Vitis vinifera & JQ012922 & $\begin{array}{l}\text { An } \mathrm{A} / \mathrm{N} \text { invertase isoform predicted to be localized } \\
\text { to the chloroplast (sub-clade } \beta \text { ). }\end{array}$ & {$[54,55]$} \\
\hline AhVI-1 & 1977 & 2282 & 73.8 & 79 & Beta vulgaris & JQ012921 & $\begin{array}{l}\text { Isoform grouped within the VI clade. Similar to a VI } \\
\text { expressed in petioles of juvenile } B \text {. vulgaris, and to } \\
\text { a soluble acid } \beta \text {-fructofuranosidase identified in } D \text {. } \\
\text { carota. Its signal peptide predicts it to be a type } \\
\text { II membrane protein that is anchored to the } \\
\text { vacuolar membrane, similarly to Arabidopsis, rice, } \\
\text { barley, and sugarcane. Membrane anchorage of } \\
\text { AhVl-1 may permit a more precise control of its } \\
\text { destination and activity. }\end{array}$ & {$[34,56,57]$} \\
\hline$A h C W I^{*}$ & 964 & 991 & - - & 75 & Beta vulgaris & JQ012923 & $\begin{array}{l}\text { Isoform grouped within the CWI clade. Has shared } \\
\text { identity with CWIs from B. vulgaris and C. rubrum. } \\
\text { Predicted to be a secretory protein having a } \\
\text { hydrophobic } 26 \text { aa signal peptide that is required } \\
\text { for co-translational insertion into the endoplasmic } \\
\text { reticulum and secretion from the cell. }\end{array}$ & {$[34,48]$} \\
\hline
\end{tabular}

The percentage of identity with the closest annotated homolog is shown. cDNAs marked with an asterisk (*) are not full-length.

'ORF = Open Reading Frame.

2 aa $=$ amino-acids.

${ }^{3} \mathrm{bp}=$ base pairs.

${ }^{4}$ Ref $=$ References. 
Table 2 Genomic sequences of two grain amaranth genes involved in sucrose and starch metabolism

\begin{tabular}{|c|c|c|c|c|c|c|}
\hline Gene & $\begin{array}{l}\text { Size } \\
(\mathrm{bp})^{1}\end{array}$ & $\begin{array}{l}\text { No. } \\
\text { Exon }\end{array}$ & $\begin{array}{c}\text { No. } \\
\text { Intron }\end{array}$ & $\begin{array}{c}\text { Accesion } \\
\text { number }\end{array}$ & Salient characteristics ${ }^{2}$ & $\operatorname{Ref}^{2}$ \\
\hline AhAGPS-1 & 5088 & $9(99-297)^{3}$ & $8(84-1048)^{3}$ & JQ034321 & $\begin{array}{l}\text { The gene is highly similar ( } 94 \% \text { identity) to the } B \text {. vulgaris AGPB1 gene } \\
\text { (GenBank X78899.1). The complexity of this gene is shared with other } \\
\text { starch metabolism genes. The presence of a large first intron (1048 bp) } \\
\text { suggests a possible role in regulating expression as observed for a } \\
\text { sucrose synthase gene in Arabidopsis. The promoter region has MYCL } \\
\text { and GCCF boxes which are needed in maize for the transcriptional } \\
\text { regulation of the waxy gene coding for a GBSS. }\end{array}$ & {$[46,58-60]$} \\
\hline
\end{tabular}

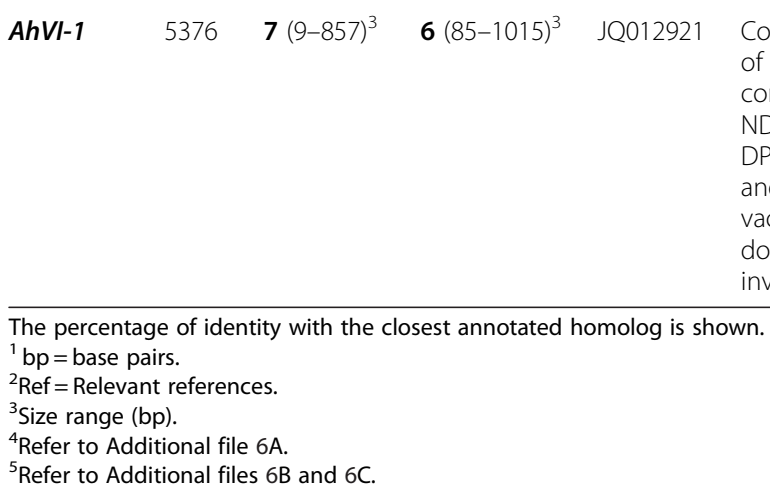

Contains the expected seven exons generally conserved in the majority [61-63] of acid invertase genes isolated from plants ${ }^{4}$. The AhVI-1 gene also contains a membrane spanning domain in exon 1 and the motifs NDPNG, partially encoded by mini-exon 2 encoding the tripeptide DPN, and WECVDF (exon 3), which are essential for catalytic activity and are conserved in this gene family ${ }^{5}$. A key feature identifying it as vacuolar invertase was that the $X$ residue in the conserved WECXDF domain corresponded to a valine residue. This is characteristic of invertases targeted to the vacuole; in the CWIs, $\mathrm{X}$ is a proline.

\author{
The percentage of identity with the closest annotated homolog is shown. \\ Size range (bp). \\ ${ }^{5}$ Refer to Additional files $6 \mathrm{~B}$ and $6 \mathrm{C}$.
}

other hand, AhVI-1 was selected from a total of four vacuolar invertase isoforms on the basis of its high similarity to a vacuolar invertase in B. vulgaris, BvVI, which has been shown to play an important role in $\mathrm{C}$ partition [34]. The only putative cell wall invertase (CWI) isoform identified so far in grain amaranth, AhCWI, is related to CWIs in B. vulgaris (BvExINV), Vicia faba (VfCWI2) and tomato (Solanum lycopersicum; SIWI1) which are known for their capacity to regulate sink strength in seeds and roots and participate in the wound response, respectively [34,35] (Additional file 3). The phylogenetic relationship between the ADP glucose pyrophosphorylases (AGP) found in grain amaranth suggests that the subunits that conforms the enzyme tetramer are being codified by at least four genes, two of which, AhAGP-L1 and -3 may be involved in stress responses. This is implied by their similarity to AGPL12 in tomato, which has been shown to be induced by salt stress in an ABA- and osmotic-stress independent way [36]. In contrast, only one small AGP subunit has been identified in grain amaranth, AhAGPS-1. This protein is related to homologs in other plants, such as tobacco, maize and pea, where they are known to participate in development programs and in stressresistance responses [37-39] (Additional file 4). The partial sequence of six plant invertase inhibitors, which are small proteins $(15-23 \mathrm{kD})$ targeted to the cell wall or vacuole in a variety of species [40], was also used to determine their phylogenetic relationships. The analysis showed that $A h \operatorname{InvI-4}$ had a close relationship to the Arabidopsis AtC/VIF-1, a confirmed vacuolar invertase inhibitor and that AhInvI1-2 resembled apoplastic- localized inhibitors involved in both development (ZMINVINH1) and stress response processes (AtC/VIF-1), respectively [41] (Additional file 5). The genomic sequences of a vacuolar invertase $(A h V I-1)$ and of a plastidial ADP-glucose pyrophosphorylase small subunit gene (AhAGPS-1) included a sizeable section of their respective promoter regions. Promoter analysis of ADPglucose pyrophosphorylase and vacuolar invertase genes indicated the presence of cis-regulatory elements that supported their responsiveness to defoliation (Additional files $6,7,8)$. Not surprisingly, the majority of the amaranth genes and proteins analyzed shared the highest level of identity with similar proteins previously reported in sugar beet, except for AhA/NI-1, which had a higher resemblance to an invertase isolated from carrot [42]. This coincided with the close phylogentic relationship shared by Amaranthus spp. and B. vulgaris [43,44]. An interesting aspect of the promoter regions of the AhAGPS-1 gene was that it had a higher representation of regulatory elements involved in defense responses than that of an orthologous gene identified in Solanum tuberosum [45]. On the other hand, a striking difference found between the promoter regions of the AhVI-I and the B. vulgaris vacuolar invertase genes, respectively, was the lower abundance, in the former, of important cis-regulatory elements of genes involved in ABA and JA signaling pathways activated in response to (a)biotic stress and wounding (e.g. ABRE, G-box and W-box motifs) (Additional file 8). The expression of the selected genes was analyzed and correlated to the changes in carbohydrate $(\mathrm{CHO})$ content and enzyme activities, as described in the following sections. 


\section{Changes in $\mathrm{CHO}$ levels produced in response to partial defoliation in $A$. cruentus}

Partial defoliation $(\approx 30 \%$ loss of leaf tissue) was produced in 30-day-old plants either by mechanical damage (mechanical defoliation, MD) or insect feeding (herbivory defoliation, HD). Measurements were made at different days post partial defoliation (dppd): 1, 5, 30 and 110 dppd in three independent experiments. The choice of these time points was based on preliminary experiments $[15,16]$.

Starch, SUC, GLC and FRC levels were determined in source leaves, stems, roots and panicles of $A$. cruentus $(A c)$ plants (Figures 1 and 2). The general trend was that all non-structural carbohydrate (NSC) levels were reduced in most tissues as a result of defoliation (Figures 1 and 2). Starch and hexoses were the NSCs more profoundly affected by defoliation. Starch was predominantly reduced in leaves of MD and HD plants compared to undamaged controls (Figure 1A), whereas hexoses were depleted in leaves, stems and roots of MD and HD plants compared to undamaged controls (Figure 2). The effect was rapid, since it occurred most dramatically at $1 \mathrm{dppd}$ and was still evident at $5 \mathrm{dppd}$ (Figures 1 and 2). Hexoses depletion at times when sucrolytic activities were high (e.g. 5 dppd; see below) suggested that their utilization rate in the defoliated plants surpassed their enzymatic release rate from sucrose. The rapid and general reduction in NSC reserves occurring in response to defoliation was very similar to the one observed when plants were $\mathrm{C}$-starved by shading for three consecutive days (Vargas-Ortiz E, unpublished data). This similarity supports our proposal that foliar starch and other $\mathrm{C}$ reserves are rapidly metabolized to sustain growth when they are depleted by factors that affect $\mathrm{C}$ acquisition in leaves, such as reduced leaf area or light limitation.

On the long term most NSC levels recovered or maintained control levels at $30 \mathrm{dppd}$, and in some isolated cases surpassed them (Figure 2). It was also evident that MD and HD led to similar changes in NSC levels, except in panicles, where HD had a strong negative effect in all NSCs except SUC (Figures 1 and 2).

Starch was the most abundant NSC reserve in the leaves of $A c$ plants (Figure 1). This agreed with the high starch accumulation in leaves of sugar beet, a close relative of amaranth [64]. Starch levels in leaves and panicles were $\sim 10$ times higher than roots and stems (Figure 1). Starch increased approximately 2 -fold during development, but the HD and MD treatments consistently decreased starch levels compared to the control plants (Figure 1). This pattern suggested that the mobilization of the ample starch reserves in leaves of $A c$ could be a key factor for recovery after defoliation. It was in agreement with the frequently observed mobilization of starch
A

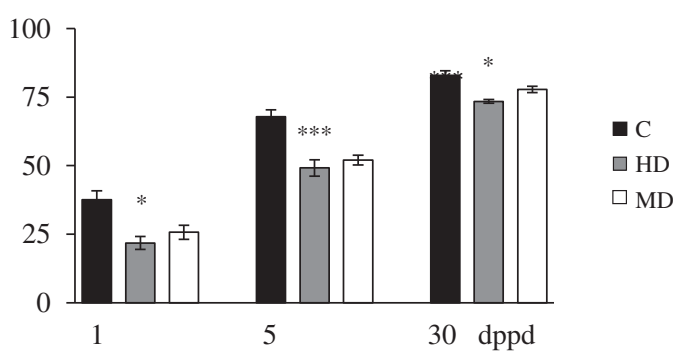

B

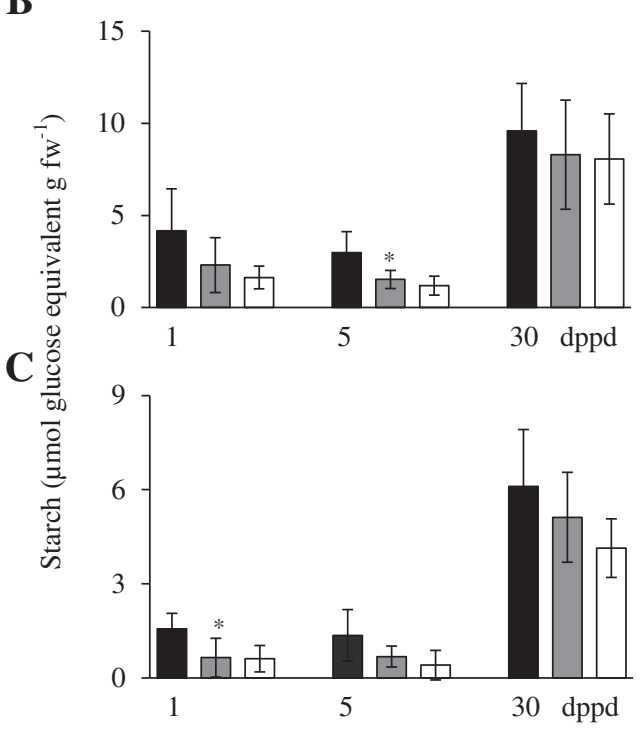

D

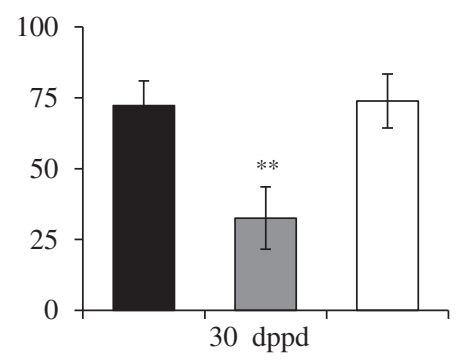

Figure 1 Starch levels measured as glucose equivalents per $\mathbf{g}$ of fresh weight at different days post partial defoliation (dppd) in (A) source leaves ${ }^{1}$, (B) stems, (C) roots and (D) panicles of intact control and defoliated Amaranthus cruentus plants. Defoliation was produced either by insect herbivory (HD) or mechanical damage (MD). Data represent means \pm standard error of three technical replicates of pooled samples taken from a representative experiment that was replicated twice. Asterisks indicate significant difference from controls at ${ }^{*} P<0.05$; ${ }^{* *} P<0.01$; ${ }^{* * *} \mathrm{P}<0.001 .{ }^{1}$ In defoliated plants, all three source leaves sampled were damaged.

reserves to sustain new plant growth after defoliation and with the proposed role of leaf and stem starch as a buffer against abiotic and biotic stresses [65]. Curiously, these results had a closer resemblance to the long-term responses to defoliation reported in woody plants than 


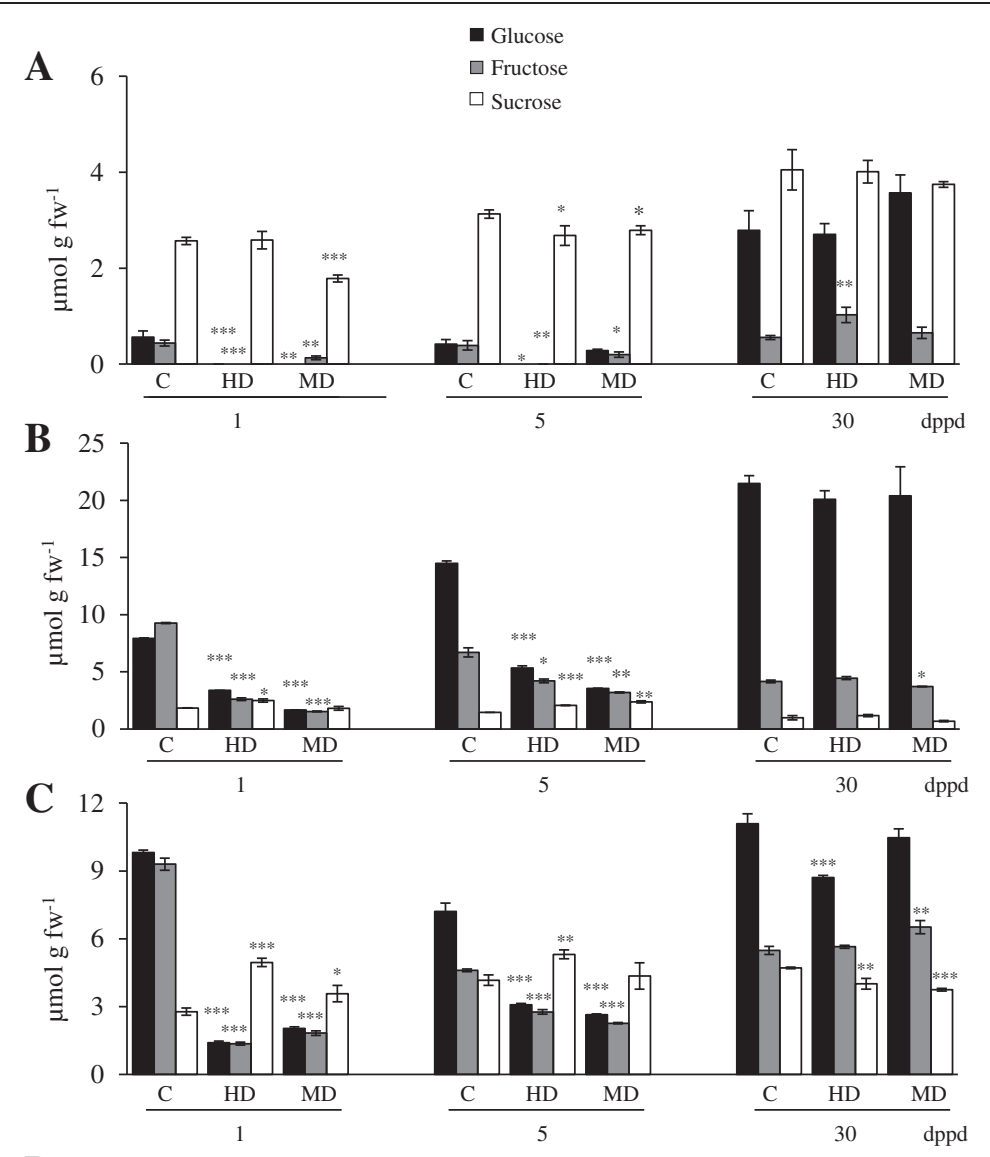

D

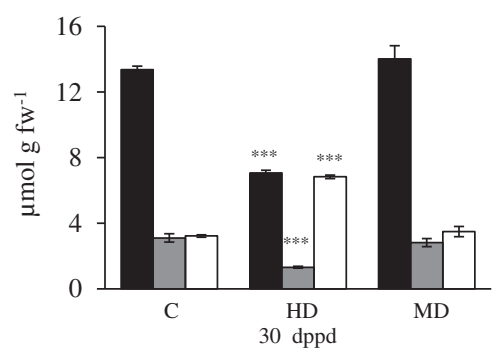

Figure 2 Sucrose, glucose and fructose levels measured at different days post partial defoliation (dppd) in (A) source leaves, (B) stems, (C) roots and (D) panicles of intact control and defoliated Amaranthus cruentus plants. Defoliation was produced either by insect herbivory (HD) or mechanical damage (MD). For further details refer to Figure 1.

to those registered in annual grasses and shrubs. In the former species, defoliation has been frequently found to cause short-term reductions in $\mathrm{C}$ stores, present primarily in leaves, but no long term depletion after repeated defoliation [66-70]. On the other hand, seasonal defoliation studies performed with $\mathrm{C}_{3}$ grasses (e.g. Agropyron spp. and Lolium perenne) and shrubs (e.g. Caragana korshinskii and Ruellia nudiflora), have reported more diverse outcomes. These include, in $L$. perenne, an accumulation of $\mathrm{C}$ reserves that was subsequently used to secure survival after repeated grazing [71]. In contrast, a drastic reduction in soluble carbon pools was detected in Agropyron bunchgrasses after severe defoliation treatments that impeded full recovery due to a limited replenishment capacity [72]. In shrubs, reduced leaf longevity and accumulation of below-ground carbon reserves allowed full compensation in terms of fruit output in defoliated R. nudiflora [73], whereas C. korshinskii relied on the preferential resource allocation to vegetative tissues for regrowth, at the cost of fruit production [74].

It must be noted that in one experiment, in which starch levels in leaves were 2-fold higher than usual, MD led to a 2-to-3 fold increase of starch in stems and roots at $30 \mathrm{dppd}$ (Additional file $9 \mathrm{~B}$ and $\mathrm{C}$ ). This suggests a plastic response to defoliation in $A c$ plants, which can sequester $C$ in less vulnerable storage tissues when 
favorable growth conditions permit the accumulation of high foliar starch. Also, the tissue- and ontogenetic dependent changes in NSC levels observed (Figures 1,2), implied that $\mathrm{C}$ resources can be preferentially allocated to certain tissues at certain developmental stages to be used for growth, reproduction or, perhaps, defense. This raised the question of which enzymes could be regulating $\mathrm{C}$ allocation in grain amaranth.

\section{Changes in SuS activities and expression in response to partial defoliation in $A$. cruentus}

The observed fluctuations in NSC levels in sink and source tissues in response to partial defoliation (Figure 2) could have been caused by changes in different sucrolytic activities present in different subcellular compartments and tissues. Therefore, the activities of SuS, neutral invertases, soluble acid and cell-wall-bound invertases were determined at different times after HD or MD. The enzymatic assays were complemented with a qPCR expression analysis of selected isoforms and genes associated with $\mathrm{C}$ allocation and transport (Tables 3,4,5,6).

$\mathrm{SuS}$ activity in undamaged plants remained relatively stable for the duration of the defoliation experiment, except for transient peaks in activity in stems and roots of 35 day-old plants (equivalent to the $5 \mathrm{dppd}$ in defoliated plants) (Figure 3). Defoliation had an evident effect on SuS activity (Figure 3). For example, in leaves, both MD and HD induced a 2- to 4-fold increase in SuS activity at 1 and 5 dppd (Figure 3A). The effect was reversed at $30 \mathrm{dppd}$, where both treatments led to a drastic reduction of SuS activity (Figure 3A). The changes of SuS activity might have reflected a shift in the metabolic status of leaves, from sink to source tissues, as they gradually recovered their NSC reserves, as observed in Figures 1 and 2.

The AhSuS-1 and AhSuS-2 genes were more sensitive to HD than to MD (Table 3 ). The latter treatment only affected the expression of these genes in stems, where they showed a contrasting behavior (Table 3; see below). Moreover, no concordance was found between the biphasic pattern of $\mathrm{AhSuS}$ gene expression in leaves of HD plants (low at 1dppd and high at $30 \mathrm{dppd}$ ) and enzyme activity levels, which were higher than controls shortly after defoliation and then dropped to almost undetectable levels at $30 \mathrm{dppd}$.

In stems of MD plants, SuS activity was temporarily induced above those in undamaged controls at 1 and 5 dppd. HD, in contrast, led to a rapid decline at $1 \mathrm{dppd}$, but maintained a long-term stability that led to higher activity levels than controls at $30 \mathrm{dppd}$ (Figure 3B). The significantly higher SuS activity that persisted in stems of HD plants at $30 \mathrm{dppd}$ coincided with the late induction of both AhSuS-1 and AhSuS-2 (Table 3). In roots,
MD had a fast inductive effect on SuS activity that was not accompanied by the induction of either of the AhSuS-1 and AhSuS-2 genes. Similarly, the $\sim 2$-fold reduction in SuS activity in panicles of HD plants was contrary to the induced expression of both $A h S u S$ genes in these tissues in HD plants (Figure 3D and Table 3). The lack of direct correlation observed between $\mathrm{AhSuS}-1$ and AhSuS-2 expression levels and SuS activity resembled the disparity observed between SuS gene expression and enzyme activity in sugar beet roots subjected to wounding or anoxia, which was attributed to post-transcriptional mechanisms $[31,75]$. The discrepancy between SuS activity and expression could also be explained by the participation of other putative SuS isoforms. Similarly to various other plant species [76], SuS genes in grain amaranth conform a multi-gene family consisting at least seven different members [30].

The systemic induction of both $\mathrm{AhSuS}$ genes and activity in stems, roots and/ or panicles of defoliated plants was consistent with the frequent induction of SuS genes in roots and/or shoots of plants under stress conditions [77]. This argues in favor of the generation of a woundderived systemic signal in defoliated amaranth plants, which could have been JA, a related oxylipin or even $\mathrm{H}_{2} \mathrm{O}_{2}$ (see below).

\section{Changes in invertase activities and expression in response to partial defoliation in $A$. cruentus}

Soluble acid invertase (SAI) activity (e.g. "vacuolar invertase") was comparatively high in leaves of damaged young Ac plants (31 and 35 days-old-plants), intermediate in stems and low in roots (Figure 4A-C). SAI activity declined sharply in all tissues of 60 days-old-plants (30 dppd), except in panicles where SAI activity levels were similar to those detected in stems of young plants (Figure 4D). In leaves, the defoliation effect on SAI was very similar to the one observed on SuS activity (except that no induction was observed at $5 \mathrm{dppd}$ in MD plants) (Figure 4A). In stems, the short term effect of HD, at 1 and $5 \mathrm{dppd}$, was negative, whereas MD was neutral (Figure 4B). In roots, the effect of defoliation was negative at $5 \mathrm{dppd}$, although a transient induction was observed in MD plants at $1 \mathrm{dppd}$, whereas increased SAI activity was detected in panicles of HD plants (Figure 4C and D).

AhVI-1 expression could explain the increase of SAI activity in leaves of $\mathrm{HD}$, at 1 and $5 \mathrm{dppd}$, and MD plants, at $5 \mathrm{dppd}$, and in stems of MD plants, at 5 dppd (Table 3). In addition, the late induction of the putative AhInvI-4 inhibitor gene predicted to target AhVI-1 [41] (Additional file 5) correlated with the abated SAI activity levels observed in leaves of HD and MD plants at $30 \mathrm{dppd}$ (Table 3 and Figure 4A). The repressed expression of this inhibitor gene observed in leaves at $1 \mathrm{dppd}$ could have also contributed to the increased SAI activity detected. 
Table 3 Relative transcript abundance of sucrolytic and related regulatory genes

\begin{tabular}{|c|c|c|c|c|c|c|}
\hline Gene $^{1}$ & Treatment & dppd & Leaf & Stem & Root & Panicle \\
\hline \multirow[t]{6}{*}{ AhSuS-1 } & $\mathrm{HD}$ & 1 & $0.18 \pm 0.00$ & $1.50 \pm 0.20$ & $2.09 \pm 0.10$ & - \\
\hline & & 5 & $1.38 \pm 0.05$ & $0.87 \pm 0.21$ & $0.83 \pm 0.08$ & - \\
\hline & & 30 & $3.01 \pm 0.24$ & $2.15 \pm 0.40$ & $1.03 \pm 0.19$ & $2.15 \pm 0.08$ \\
\hline & $\mathrm{MD}$ & 1 & $0.63 \pm 0.06$ & $\mathrm{NE}$ & $0.95 \pm 0.16$ & - \\
\hline & & 5 & $0.87 \pm 0.07$ & $0.84 \pm 0.07$ & $0.53 \pm 0.08$ & - \\
\hline & & 30 & $1.23 \pm 0.27$ & $1.06 \pm 0.30$ & $0.55 \pm 0.01$ & $1.47 \pm 0.35$ \\
\hline \multirow[t]{6}{*}{ AhSuS-2 } & $H D$ & 1 & $0.36 \pm 0.03$ & $2.10 \pm 0.10$ & $1.64 \pm 0.21$ & - \\
\hline & & 5 & $1.21 \pm 0.02$ & $0.77 \pm 0.09$ & $1.52 \pm 0.03$ & - \\
\hline & & 30 & $2.62 \pm 0.07$ & $1.58 \pm 0.14$ & $1.77 \pm 0.25$ & $1.91 \pm 0.05$ \\
\hline & $\mathrm{MD}$ & 1 & $0.76 \pm 0.04$ & $2.36 \pm 0.41$ & $1.19 \pm 0.10$ & - \\
\hline & & 5 & $0.86 \pm 0.08$ & $0.66 \pm 0.01$ & $0.86 \pm 0.23$ & - \\
\hline & & 30 & $1.13 \pm 0.08$ & $2.00 \pm 0.21$ & $1.10 \pm 0.06$ & $1.07 \pm 0.04$ \\
\hline \multirow[t]{6}{*}{$A h V I-1$} & $\mathrm{HD}$ & 1 & $2.19 \pm 0.18$ & $3.00 \pm 0.90$ & $1.37 \pm 0.13$ & - \\
\hline & & 5 & $3.74 \pm 0.00$ & $6.58 \pm 0.26$ & $2.49 \pm 0.05$ & - \\
\hline & & 30 & $0.91 \pm 0.25$ & $1.12 \pm 0.15$ & $1.20 \pm 0.18$ & $1.38 \pm 0.02$ \\
\hline & $\mathrm{MD}$ & 1 & $0.82 \pm 0.01$ & $1.25 \pm 0.06$ & $1.96 \pm 0.14$ & - \\
\hline & & 5 & $2.57 \pm 0.06$ & $2.71 \pm 0.76$ & $1.30 \pm 0.43$ & - \\
\hline & & 30 & $1.24 \pm 0.04$ & $1.11 \pm 0.13$ & $0.77 \pm 0.06$ & $1.65 \pm 0.04$ \\
\hline \multirow[t]{6}{*}{ Ahlnvl-4 (VI inhibitor) } & $\mathrm{HD}$ & 1 & $0.40 \pm 0.17$ & $1.00 \pm 0.30$ & $1.54 \pm 0.11$ & - \\
\hline & & 5 & $1.00 \pm 0.01$ & $0.89 \pm 0.34$ & $0.78 \pm 0.22$ & - \\
\hline & & 30 & $1.77 \pm 0.29$ & $0.60 \pm 0.06$ & $0.72 \pm 0.18$ & $1.30 \pm 0.22$ \\
\hline & $\mathrm{MD}$ & 1 & $0.68 \pm 0.40$ & $1.12 \pm 0.39$ & $0.86 \pm 0.09$ & - \\
\hline & & 5 & $0.96 \pm 0.06$ & $0.61 \pm 0.34$ & $0.61 \pm 0.16$ & - \\
\hline & & 30 & $2.89 \pm 0.53$ & $1.86 \pm 0.04$ & $0.98 \pm 0.10$ & $0.76 \pm 0.09$ \\
\hline \multirow[t]{6}{*}{$A h-\gamma V P E$} & $\mathrm{HD}$ & 1 & $4.40 \pm 0.54$ & $0.70 \pm 0.10$ & $1.41 \pm 0.19$ & - \\
\hline & & 5 & $0.10 \pm 0.01$ & $1.91 \pm 0.25$ & $2.74 \pm 0.52$ & - \\
\hline & & 30 & $5.83 \pm 0.92$ & $0.98 \pm 0.30$ & $1.61 \pm 0.13$ & $2.09 \pm 0.11$ \\
\hline & $\mathrm{MD}$ & 1 & $0.49 \pm 0.20$ & $0.59 \pm 0.27$ & $1.15 \pm 0.11$ & - \\
\hline & & 5 & $0.35 \pm 0.04$ & $0.39 \pm 0.12$ & $0.13 \pm 0.01$ & - \\
\hline & & 30 & $3.59 \pm 0.01$ & $1.10 \pm 0.55$ & $1.39 \pm 0.14$ & $1.76 \pm 0.09$ \\
\hline \multirow[t]{6}{*}{ Ahlnvl-2 (CWI inhibitor) } & $\mathrm{HD}$ & 1 & $0.23 \pm 0.02$ & $1.40 \pm 0.20$ & $1.51 \pm 0.23$ & - \\
\hline & & 5 & $1.59 \pm 0.14$ & $0.85 \pm 0.06$ & $0.75 \pm 0.10$ & - \\
\hline & & 30 & $1.94 \pm 0.28$ & $1.12 \pm 0.02$ & $0.97 \pm 0.03$ & $1.39 \pm 0.16$ \\
\hline & MD & 1 & $0.35 \pm 0.19$ & $2.45 \pm 1.69$ & $1.29 \pm 0.16$ & - \\
\hline & & 5 & $1.30 \pm 0.00$ & $0.56 \pm 0.04$ & $1.00 \pm 0.06$ & - \\
\hline & & 30 & $0.88 \pm 0.01$ & $2.56 \pm 0.15$ & $0.94 \pm 0.16$ & $1.26 \pm 0.10$ \\
\hline \multirow[t]{6}{*}{ Ahlnvl-1 (CWI inhibitor) } & $H D$ & 1 & $0.20 \pm 0.03$ & ${ }^{2} \mathrm{NE}$ & $0.29 \pm 0.06$ & - \\
\hline & & 5 & $0.53 \pm 0.09$ & $0.96 \pm 0.01$ & $0.98 \pm 0.00$ & \\
\hline & & 30 & $1.03 \pm 0.13$ & $0.91 \pm 0.16$ & $0.70 \pm 0.03$ & $1.05 \pm 0.13$ \\
\hline & $\mathrm{MD}$ & 1 & $0.70 \pm 0.05$ & $\mathrm{NE}$ & $1.22 \pm 0.16$ & - \\
\hline & & 5 & $0.63 \pm 0.04$ & $1.19 \pm 0.51$ & $1.86 \pm 0.54$ & - \\
\hline & & 30 & $0.94 \pm 0.22$ & $2.48 \pm 0.23$ & $2.08 \pm 0.19$ & $0.93 \pm 0.15$ \\
\hline \multirow[t]{2}{*}{$A h A / N I-1$} & $H D$ & 1 & $0.09 \pm 0.20$ & $0.79 \pm 0.26$ & $\mathrm{NE}$ & - \\
\hline & & 5 & $0.94 \pm 0.37$ & $3.59 \pm 0.31$ & $\mathrm{NE}$ & - \\
\hline
\end{tabular}


Table 3 Relative transcript abundance of sucrolytic and related regulatory genes (Continued)

\begin{tabular}{|c|c|c|c|c|c|c|}
\hline & & 30 & $\mathrm{NE}$ & $1.38 \pm 0.16$ & $\mathrm{NE}$ & $\mathrm{NE}$ \\
\hline & $M D$ & 1 & $0.11 \pm 0.20$ & $1.64 \pm 0.06$ & $\mathrm{NE}$ & - \\
\hline & & 5 & $0.22 \pm 0.47$ & $6.10 \pm 0.22$ & $\mathrm{NE}$ & - \\
\hline & & 30 & $\mathrm{NE}$ & $0.80 \pm 0.17$ & $\mathrm{NE}$ & $\mathrm{NE}$ \\
\hline \multirow[t]{6}{*}{ AhSNRK-1 } & $H D$ & 1 & $1.87 \pm 0.05$ & - & - & - \\
\hline & & 5 & $1.29 \pm 0.38$ & - & - & - \\
\hline & & 30 & $0.40 \pm 0.27$ & - & - & - \\
\hline & $M D$ & 1 & $0.18 \pm 0.16$ & - & - & - \\
\hline & & 5 & $4.70 \pm 0.50$ & - & - & - \\
\hline & & 30 & $3.87 \pm 0.27$ & - & - & - \\
\hline
\end{tabular}

Expression was measured at different days post partial defoliation (dppd) by insect (HD) or mechanical (MD) damage in different plant tissues of Amaranthus cruentus. Transcript levels were measured by qRT-PCR. Values represent means \pm SE of a representative experiment with three replicates. They indicate the foldchange in gene expression levels present in tissues of defoliated plants relative to those in tissues of intact control plants. A given gene was considered induced when its relative expression values was $\geq 1.5$, whereas it was considered repressed when its relative expression values was $\leq 0.5$. These are shown in bold text and bold italics, respectively.

${ }^{1}$ The expression of the neutral invertase $A h A / N I-2$ and sucrose phosphate synthase (AhSPS) genes was not detected in any of the tissues examined.

${ }^{2} \mathrm{NE}=$ Not Expressed.

The expression of a vacuolar processing enzyme gamma gene $(A h-\gamma V P E)$ in response to defoliation was also monitored in this study because of its known participation in the regulation of vacuolar invertase activity in planta $[56,78,79]$. However, only its late induction in leaves in response to both $\mathrm{HD}$ and $\mathrm{MD}$, at $30 \mathrm{dppd}$, and its early and strong repression in MD plants, at $1 \mathrm{dppd}$, coincided with modified SAI activity levels (Table 3 and Figure 4). Curiously, a strong repression of this gene was observed in leaves of defoliated plants at $5 \mathrm{dppd}$. Apart from leaves, an evident damage-dependent effect on the expression of this gene was observed at this time point in stems and roots, being positive in HD plants and negative in MD plants. The general lack of correlation between $A h-\gamma V P E$ expression and SAI levels in $A c$ indicated other possible functions of this gene in stressed plants, similar to what was recently reported in Nicotiana benthamiana [80].

Increased $A h V I-1$ transcript abundance and acid invertase activity in damaged leaves and sink tissues of defoliated $A c$ plants was in accordance with the known up-regulation of invertases often observed after leaf damage by wounding or insect herbivory in several plant species, where they are believed to contribute to the altered source-sink relationships occurring in damaged leaves $[21,35,81,82]$. Moreover, the pattern of $A h V I-1$ expression and SAI activity suggest that this particular sucrolytic enzyme, perhaps in combination with SuS activity (see above), may play an important role in the early utilization of $\mathrm{C}$ reserves, predominantly in leaves, to support growth under defoliation stress in Ac plants.

Insoluble (e.g. "cell wall-bound") acid invertase (IAI) activity was, in general, the most active type of invertase detected in $A c$ plants. IAI levels were similar in leaves and stems and lower in roots, of undamaged young $A c$ plants and diminished in these tissues as plants aged. IAI activity in young panicles was relatively high (Figure 5). The defoliation effect on IAI activity in leaves was sporadic, only induced in leaves by HD and MD at 1 and $5 \mathrm{dppd}$, respectively, and in stems, at $5 \mathrm{dppd}$ (Figure 5A and B). These minor changes in CWI activity were mirrored by no apparent changes in $A h C W I$ gene expression levels (results not shown).

AhInvI-2 (coding for a putative inhibitor of CWIs) showed widely different patterns of expression (Table 3 and Figure 5). The expression of this inhibitor gene in leaves of HD plants also showed an inverse correlation with the pattern of CWI activity (Figure 5A and Table 3), since its down-regulation, at $1 \mathrm{dppd}$, correlated with augmented levels of CWI activity. The AhInvI-1 gene, coding for another putative CWI inhibitor, also showed tissue- and damage-dependent expression, since HD led to strong and transient repression at $1 \mathrm{dppd}$ in all tissues examined, whereas MD mostly led to a retarded to late induction, at 5 and $30 \mathrm{dppd}$, in stem and leaves. However, the target enzymes and physiological roles of these particular inhibitors in SUC metabolism in Ac plants remain to be determined.

Neutral (e.g. "cytoplasmic") invertase (NI) was, in general, the least active type of invertase detected in $A c$ plants. NI activity levels did not vary much at first in all tissues of undamaged young $A c$ plants examined, but similarly to SAI and IAI, NI activity declined sharply in 60 days-old-plants, reaching undetectable levels in leaves (Figure 6). This coincided with the low to undetectable levels of expression of the neutral invertase $A h A / N I-1$ gene in leaves and roots of control and defoliated plants at 30 dppd (Table 3). Similar to other sucrolytic 
Table 4 Relative transcript abundance of genes involved in starch biosynthesis or breakdown

\begin{tabular}{|c|c|c|c|c|c|c|}
\hline Gene $^{1}$ & Treatment & dppd & Leaf & Stem & Root & Panicle \\
\hline \multirow[t]{6}{*}{ AhAGPS-1 } & $\mathrm{HD}$ & 1 & $0.99 \pm 0.38$ & $0.80 \pm 0.11$ & $1.24 \pm 0.13$ & - \\
\hline & & 5 & $1.17 \pm 0.11$ & $0.49 \pm 0.09$ & $0.59 \pm 0.07$ & - \\
\hline & & 30 & $0.65 \pm 0.25$ & $0.31 \pm 0.13$ & $0.74 \pm 0.04$ & $1.30 \pm 0.14$ \\
\hline & $\mathrm{MD}$ & 1 & $1.06 \pm 0.47$ & $1.88 \pm 0.57$ & $1.25 \pm 0.14$ & - \\
\hline & & 5 & $1.68 \pm 0.23$ & $1.04 \pm 0.24$ & $1.08 \pm 0.29$ & - \\
\hline & & 30 & $0.69 \pm 0.04$ & $1.12 \pm 0.25$ & $1.36 \pm 0.21$ & $1.13 \pm 0.18$ \\
\hline \multirow[t]{6}{*}{ AhAGPL-1 } & $\mathrm{HD}$ & 1 & $0.17 \pm 0.02$ & ${ }^{2} \mathrm{NE}$ & $1.14 \pm 0.16$ & - \\
\hline & & 5 & $0.87 \pm 0.15$ & $0.85 \pm 0.25$ & $0.86 \pm 0.22$ & - \\
\hline & & 30 & $1.10 \pm 0.12$ & $0.74 \pm 0.00$ & $1.02 \pm 0.09$ & $0.87 \pm 0.33$ \\
\hline & $\mathrm{MD}$ & 1 & $0.40 \pm 0.01$ & $1.19 \pm 0.02$ & $0.80 \pm 0.11$ & - \\
\hline & & 5 & $0.77 \pm 0.17$ & $0.49 \pm 0.11$ & $0.55 \pm 0.13$ & - \\
\hline & & 30 & $0.53 \pm 0.01$ & $0.97 \pm 0.18$ & $0.55 \pm 0.08$ & $0.74 \pm 0.16$ \\
\hline \multirow[t]{6}{*}{ AhAGPL-2 } & $\mathrm{HD}$ & 1 & $1.31 \pm 0.13$ & $0.90 \pm 0.00$ & $2.08 \pm 1.02$ & - \\
\hline & & 5 & $1.98 \pm 0.10$ & $1.87 \pm 0.37$ & $3.12 \pm 0.27$ & - \\
\hline & & 30 & $0.68 \pm 0.22$ & $1.36 \pm 0.16$ & $2.11 \pm 0.51$ & $2.19 \pm 0.11$ \\
\hline & $\mathrm{MD}$ & 1 & $0.92 \pm 0.15$ & $1.29 \pm 0.35$ & $1.12 \pm 1.06$ & - \\
\hline & & 5 & $1.46 \pm 0.18$ & $1.16 \pm 0.25$ & $0.88 \pm 0.21$ & - \\
\hline & & 30 & $0.88 \pm 0.01$ & $2.56 \pm 0.15$ & $0.94 \pm 0.16$ & $1.26 \pm 0.10$ \\
\hline \multirow[t]{6}{*}{ AhAGBSS } & $\mathrm{HD}$ & 1 & $1.10 \pm 0.18$ & $0.64 \pm 0.10$ & $\mathrm{NE}$ & - \\
\hline & & 5 & $0.92 \pm 0.05$ & $0.55 \pm 0.33$ & NE & - \\
\hline & & 30 & $0.35 \pm 0.00$ & $0.95 \pm 0.05$ & $\mathrm{NE}$ & $1.00 \pm 0.31$ \\
\hline & $\mathrm{MD}$ & 1 & $1.22 \pm 0.17$ & $0.61 \pm 0.19$ & NE & - \\
\hline & & 5 & $0.47 \pm 0.28$ & $0.54 \pm 0.13$ & NE & - \\
\hline & & 30 & $0.55 \pm 0.99$ & $1.27 \pm 0.12$ & NE & $0.56 \pm 0.67$ \\
\hline \multirow[t]{6}{*}{ AhSS-IV } & $\mathrm{HD}$ & 1 & $0.17 \pm 0.38$ & - & - & - \\
\hline & & 5 & $0.92 \pm 0.54$ & - & - & - \\
\hline & & 30 & $39.64 \pm 0.60$ & - & - & - \\
\hline & $\mathrm{MD}$ & 1 & $1.38 \pm 0.08$ & - & - & - \\
\hline & & 5 & $0.68 \pm 0.06$ & - & - & - \\
\hline & & 30 & $9.59 \pm 0.18$ & - & - & - \\
\hline \multirow[t]{6}{*}{$A h B M Y-1$} & $\mathrm{HD}$ & 1 & $2.10 \pm 0.45$ & - & - & - \\
\hline & & 5 & $0.44 \pm 0.37$ & - & - & - \\
\hline & & 30 & $\mathrm{NE}$ & - & - & - \\
\hline & MD & 1 & $0.78 \pm 0.64$ & - & - & - \\
\hline & & 5 & $12.12 \pm 0.31$ & - & - & - \\
\hline & & 30 & $\mathrm{NE}$ & - & - & - \\
\hline
\end{tabular}

Expression was measured at different days post partial defoliation (dppd) by insect (HD) or mechanical (MD) damage in different plant tissues of Amaranthus cruentus. Refer to Table 3 for further details.

${ }^{1}$ The expression of the soluble starch synthase AhSS-III genes was not detected in any of the tissues examined.

${ }^{2} \mathrm{NE}=$ Not Expressed.

enzymes, the development-related decrease in NI activity was not observed in panicles, where levels remained similar to those detected in younger vegetative tissues (Figure 6D). However, the gene expression assays indicated that the persistent NI activity observed in panicles was not due to the $A h A / N I-1$ gene, where the expression of this gene was not detected. On the other hand, the strong up-regulation of this gene at $5 \mathrm{dppd}$ in stems of HD and MD plants coincided only with the significantly higher NI activity levels in MD stems. No such correlation was observed in older stems, where the unexpectedly high activity detected at $30 \mathrm{dppd}$ in HD plants, was 
Table 5 Relative transcript abundance of transport genes associated with carbohydrate metabolism and/or sink-source relationships

\begin{tabular}{|c|c|c|c|c|c|c|}
\hline Gene $^{1}$ & Treatment & dppd & Leaf & Stem & Root & Panicle \\
\hline \multirow[t]{6}{*}{ AhSUT-1 } & $\mathrm{HD}$ & 1 & $3.04 \pm 0.03$ & ${ }^{2} \mathrm{NE}$ & $1.18 \pm 0.14$ & - \\
\hline & & 5 & $1.11 \pm 0.01$ & $0.63 \pm 0.10$ & $0.32 \pm 0.04$ & - \\
\hline & & 30 & $0.90 \pm 0.12$ & $1.59 \pm 0.10$ & $1.16 \pm 0.05$ & $1.58 \pm 0.08$ \\
\hline & $\mathrm{MD}$ & 1 & $1.23 \pm 0.10$ & $\mathrm{NE}$ & $0.68 \pm 0.00$ & - \\
\hline & & 5 & $0.69 \pm 0.01$ & $0.69 \pm 0.05$ & $0.63 \pm 0.03$ & - \\
\hline & & 30 & $0.70 \pm 0.00$ & $1.05 \pm 0.00$ & $0.57 \pm 0.01$ & $1.11 \pm 0.03$ \\
\hline \multirow[t]{6}{*}{ AhPPT } & $\mathrm{HD}$ & 1 & $0.15 \pm 0.06$ & $0.79 \pm 0.25$ & $1.15 \pm 0.13$ & - \\
\hline & & 5 & $2.03 \pm 0.05$ & $0.23 \pm 0.21$ & $22.09 \pm 0.64$ & - \\
\hline & & 30 & $1.28 \pm 0.61$ & $1.09 \pm 0.04$ & $1.43 \pm 0.64$ & $0.88 \pm 0.03$ \\
\hline & $\mathrm{MD}$ & 1 & $1.44 \pm 0.27$ & $1.28 \pm 0.12$ & $2.32 \pm 0.08$ & - \\
\hline & & 5 & $1.91 \pm 0.05$ & $2.54 \pm 0.31$ & $25.45 \pm 1.29$ & - \\
\hline & & 30 & $0.35 \pm 0.03$ & $0.94 \pm 0.11$ & $6.86 \pm 0.51$ & $0.73 \pm 0.29$ \\
\hline
\end{tabular}

Expression was measured at different days post partial defoliation (dppd) by insect (HD) or mechanical (MD) damage in different plant tissues of Amaranthus cruentus. Refer to Table 3 for further details.

${ }^{1}$ The expression of the Glucose-6-phosphate transporter AhG6PT gene was not detected in any of the tissues examined.

${ }^{2} \mathrm{NE}=$ Not Expressed.

not accompanied by a concomitant increase in $A h A / N I-$ 1 expression (Figure 6B and Table 3). The AhA/NI-1 expression pattern observed suggested a rigid tissuespecificity, since it was not detected in roots and panicles, was mostly down-regulated in leaves, and was strongly induced in stems at $5 \mathrm{dppd}$. This likewise suggests the participation of other $A h A / N I$ genes in determining defoliation-induced changes in alkaline/ neutral invertase activity in the cytoplasm, and possibly in plastids and/ or mitochondria [83]. This is in agreement with

Table 6 Relative transcript abundance of wound-response- (AhKTI), jasmonic acid- (AhLOX2) and senescence/ development- (AhSAG) marker genes

\begin{tabular}{|c|c|c|c|c|c|c|}
\hline Gene & Treatment & dppd & Leaf & Stem & Root & Panicle \\
\hline \multirow[t]{6}{*}{ AhKTI } & $\mathrm{HD}$ & 1 & $5.18 \pm 0.70$ & $0.90 \pm 0.20$ & $2.04 \pm 0.51$ & - \\
\hline & & 5 & $6.40 \pm 0.69$ & $0.87 \pm 0.02$ & $1.06 \pm 0.06$ & - \\
\hline & & 30 & $0.77 \pm 0.19$ & $1.44 \pm 0.03$ & $1.08 \pm 0.12$ & $1.54 \pm 0.30$ \\
\hline & $\mathrm{MD}$ & 1 & $1.66 \pm 0.85$ & $6.40 \pm 0.10$ & $0.94 \pm 0.23$ & - \\
\hline & & 5 & $3.22 \pm 0.10$ & $1.19 \pm 0.36$ & $1.92 \pm 0.36$ & - \\
\hline & & 30 & $0.20 \pm 0.03$ & $2.49 \pm 0.17$ & $0.74 \pm 0.25$ & $1.46 \pm 0.24$ \\
\hline \multirow[t]{6}{*}{ AhLOX2 } & $\mathrm{HD}$ & 1 & $5.39 \pm 0.53$ & $0.89 \pm 0.10$ & $0.59 \pm 0.29$ & - \\
\hline & & 5 & $2.09 \pm 0.00$ & $0.14 \pm 0.10$ & ${ }^{1} \mathrm{NE}$ & - \\
\hline & & 30 & $1.59 \pm 0.03$ & $1.22 \pm 0.15$ & $\mathrm{NE}$ & $1.36 \pm 0.04$ \\
\hline & $\mathrm{MD}$ & 1 & $0.71 \pm 0.83$ & $1.18 \pm 0.16$ & $1.51 \pm 0.46$ & - \\
\hline & & 5 & $0.97 \pm 0.03$ & $0.24 \pm 0.03$ & NE & - \\
\hline & & 30 & $1.29 \pm 0.18$ & $1.46 \pm 0.03$ & NE & $0.75 \pm 0.08$ \\
\hline \multirow[t]{6}{*}{ AhSAG } & $\mathrm{HD}$ & 1 & $0.10 \pm 0.04$ & NE & $1.58 \pm 0.48$ & - \\
\hline & & 5 & $1.80 \pm 0.41$ & $0.56 \pm 0.18$ & $0.84 \pm 0.01$ & - \\
\hline & & 30 & $4.38 \pm 0.13$ & NE & $1.07 \pm 0.11$ & $26.0 \pm 0.00$ \\
\hline & $\mathrm{MD}$ & 1 & $0.70 \pm 0.05$ & $0.12 \pm 0.00$ & $2.02 \pm 0.32$ & - \\
\hline & & 5 & $1.27 \pm 0.01$ & $0.73 \pm 0.25$ & $1.14 \pm 0.07$ & - \\
\hline & & 30 & $1.41 \pm 0.02$ & $1.55 \pm 0.05$ & $1.03 \pm 0.10$ & $1.28 \pm 0.16$ \\
\hline
\end{tabular}

Expression was measured at different days post partial defoliation (dppd) by insect (HD) or mechanical (MD) damage in different plant tissues of Amaranthus cruentus. Refer to Table 3 for further details.

${ }^{1} \mathrm{NE}=$ Not Expressed. 


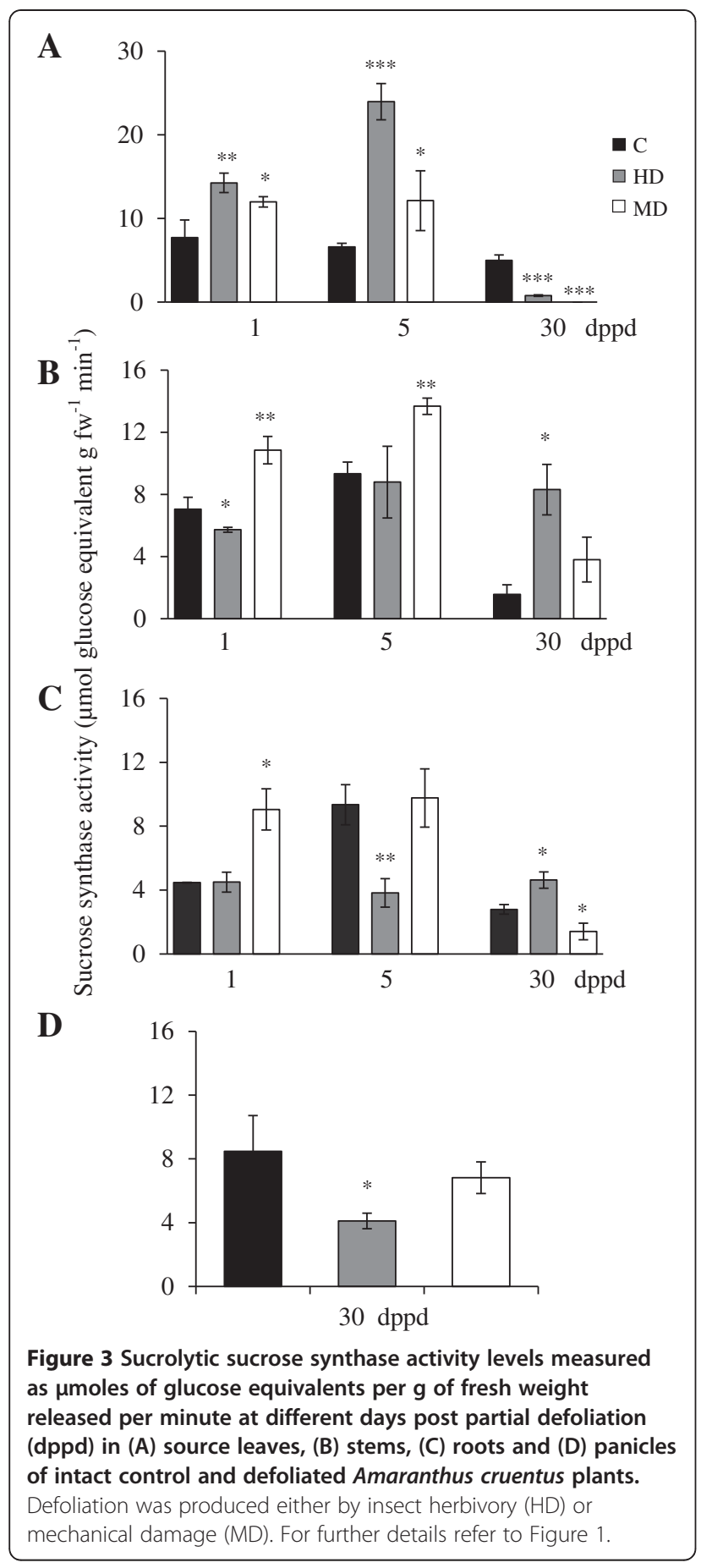

the detection of at least 14 other putative NI isoforms in grain amaranth [30].

\section{Genes of starch metabolism in response to partial} defoliation in $A$. cruentus

The expression of AhAGPS-1 and AhGBSS was mostly unaffected or down-regulated by defoliation (Table 4). Moreover, no expression of the soluble starch synthases
A

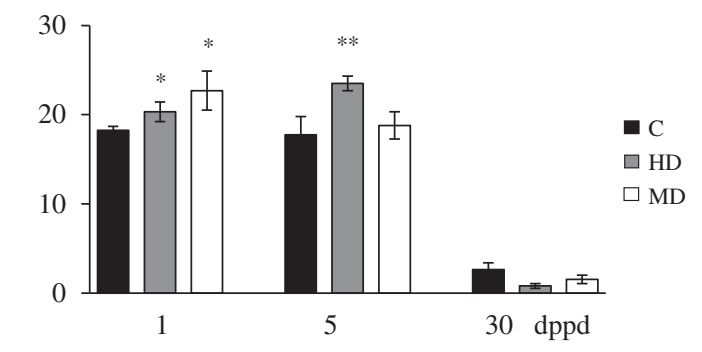

B

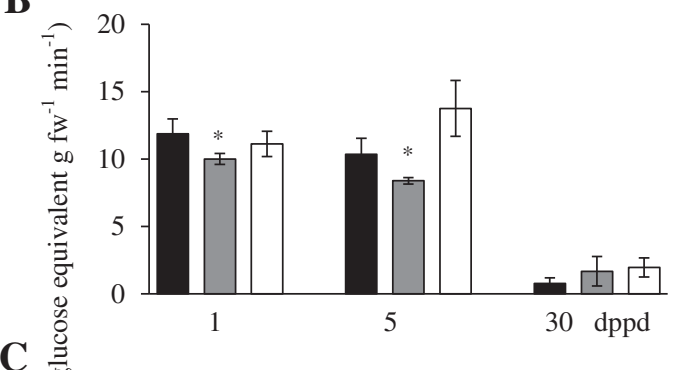

C

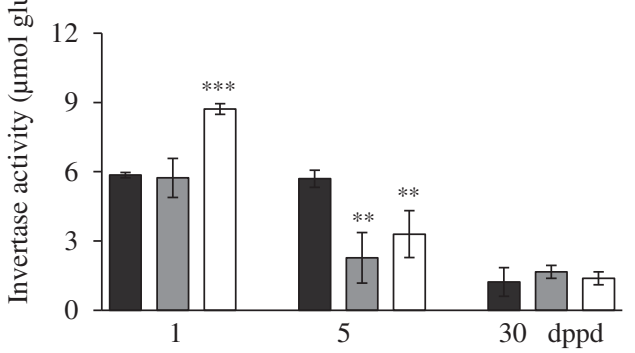

D

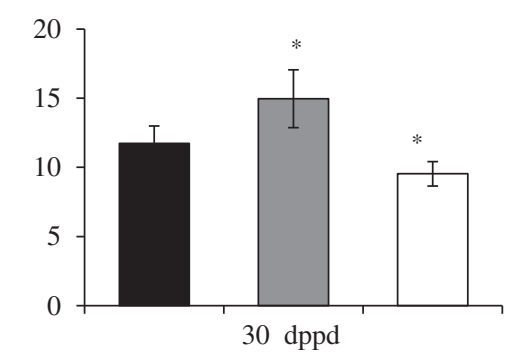

Figure 4 Soluble acid (vacuolar) invertase (SAI) activity levels measured as $\mu$ moles of glucose equivalents per $g$ of fresh weight released per minute at different days post partial defoliation (dppd) in (A) source leaves, (B) stems, (C) roots and (D) panicles of intact control and defoliated Amaranthus cruentus plants. Defoliation was produced either by insect herbivory (HD) or mechanical damage (MD). For further details refer to Figure 1.

class III gene (AhSS-III) was detected. In contrast, the two AhAGPL genes examined in this study, showed completely different patterns of expression in response to defoliation, both with respect to AhAGPS-1 and to each other (Table 4). Defoliation had a neutral to negative effect on the expression of $A h A G P L-1$, and was most strongly manifested at the early stages after defoliation ( 1 and 5 dppd) in leaves and stems of damaged plants. In contrast, AhAGPL-2 was shown to be highly sensitive 


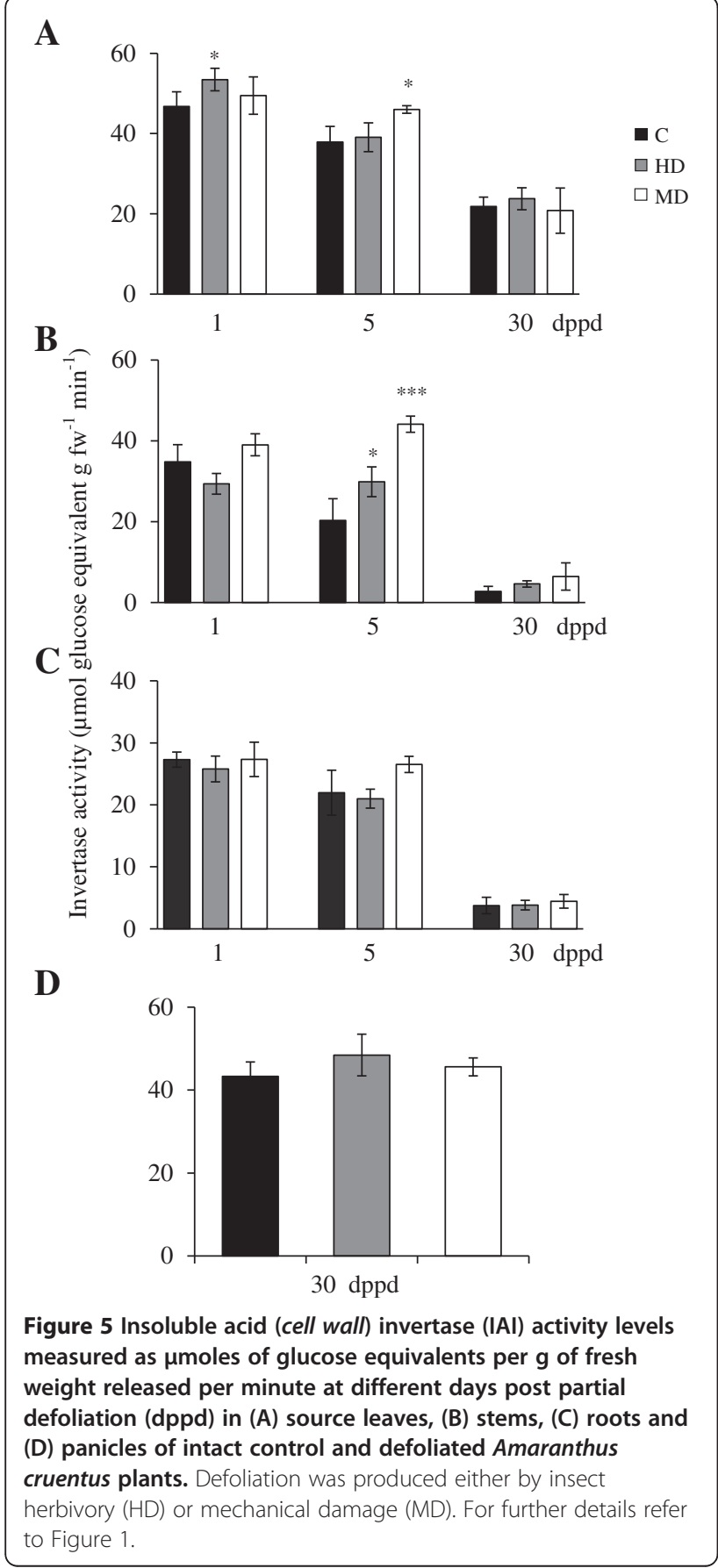

to HD plants in a time- and tissue dependent manner, as manifested by its induced expression in all tissues examined, particularly at $5 \mathrm{dppd}$, and its consistent upregulation in roots at all times after HD. MD was a weaker stimulus and did not lead to systemic induction in roots. Interestingly, defoliation by both means strongly induced this gene in panicles, which was not reflected by starch accumulation in these tissues. These

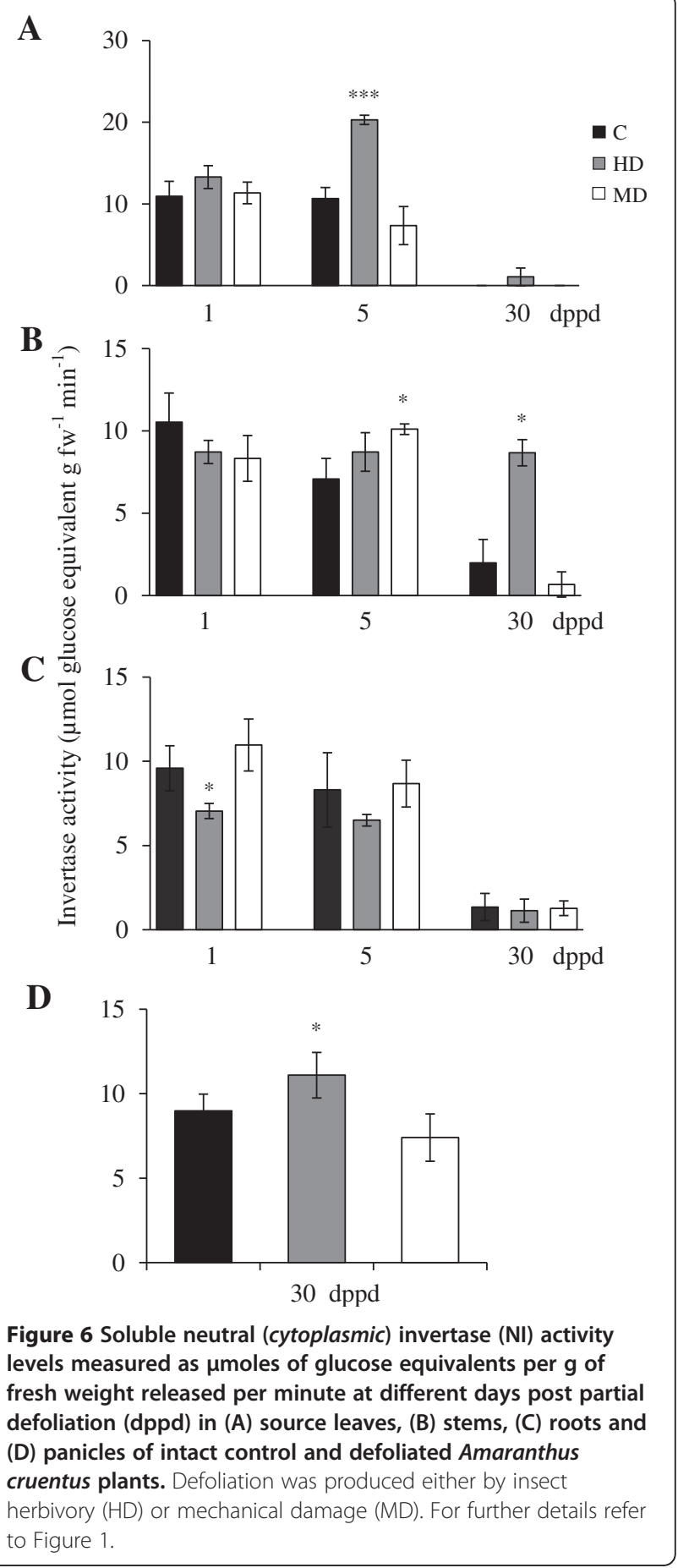

above results show that the expression of these starch biosynthesis genes in $A c$ plants is tissue-dependent and is influenced by the type of damage used for defoliation. However, the expression patterns did not coincide with the short- and long-term changes in starch levels observed in response to defoliation. This could be reflecting the complex post-translational regulation of starch synthesis known to operate in plants [84-86]. 
However, the strong and late expression of AhSS-IV, observed in leaves of both $\mathrm{HD}$ and MD plants at 30 dppd, could have contributed to the recovery of foliar starch levels in defoliated plants, similar to those in intact controls (Table 4). This possibility is supported by the important role played by soluble starch synthase genes in starch biosynthesis in Arabidopsis $[87,88]$.

On the other hand, the short-term reduction of the leaf starch reserves which was followed by a subsequent recovery, correlated inversely with the pattern of amylolytic activity shown in Figure 7. Hence, induced activity at 1 and 5 dppd (except in HD plants at 5 dppd), coincided with reduced starch levels, whereas an almost two-fold reduction of activity at $30 \mathrm{dppd}$ might have been associated with the recovery of foliar starch levels in defoliated plants. The expression pattern of a $\beta$ amylase-1 gene in leaves of defoliated plants (Table 4) was also consistent with the observed changes in both starch levels and amylolytic activity. These results were in agreement with a report showing that starch breakdown is the primary function of $\beta$-amylase in plants [89], and also with several studies in which the starch degradation produced in response to defoliation was found to correlate with augmented amylolytic activity and/or induced amylase gene expression [90-92].

The induced expression of a putative SnRK1 regulatory gene in leaves of defoliated plants suggests the involvement of this gene in the control of $C$ partitioning produced in response to leaf loss, presumably to alter resource allocation to allow increased tolerance to defoliation, similarly to what was reported in wild tobacco [93]. Interestingly, the expression of this gene was fast and transient in HD plants, whereas it was delayed and persistent in MD plants (Table 4).
Changes in the expression of a sucrose transporter gene (AhSUT1) produced in response to partial defoliation in $A$. cruentus

Even though the mechanism of phloem loading in $A c$ plants is not known, the identification of AhSUT1, coding for a sucrose transporter gene, supports the participation of an apoplastic phloem loading process, similarly to what has been reported in several other plant species [94].

This gene was also differentially affected by the way $A c$ plants were defoliated, being more responsive to $\mathrm{HD}$ than to MD. The effect was also tissue-, and timedependent, since AhSUT1 was strongly induced in HD plants in leaves (at $1 \mathrm{dppd}$ ) and panicles, whereas the effect in roots was negative at $5 \mathrm{dppd}$; roots of MD plants also showed repression of this gene at $30 \mathrm{dppd}$. In stems, a strong early repression was observed in both HD and MD plants at $1 \mathrm{dppd}$. In HD, this effect was reversed at 30 dppd (Table 5). A close resemblance with several other studies showing a rapid and transient expression of SUC transporters in response to defoliation by grazing or insect herbivory $[21,71,90,95,96]$, supports an important role for AhSUT1, as a facilitator of SUC transport from the leaves, in the tolerance response to defoliation in grain amaranth.

Changes in the expression of a putative phosphoenolpyruvate/ Pi translocator $(A h P P T)$ gene in response to partial defoliation in $A$. cruentus: possible relationship with transient fatty acid accumulation in roots.

In contrast to most genes examined, the pattern of expression of a putative phosphoenolpyruvate/ Pi translocator $(A h P P T)$ showed that, except for a few cases, MD induced a generalized accumulation of $A h P P T$ transcripts in all tissues examined, which was particularly

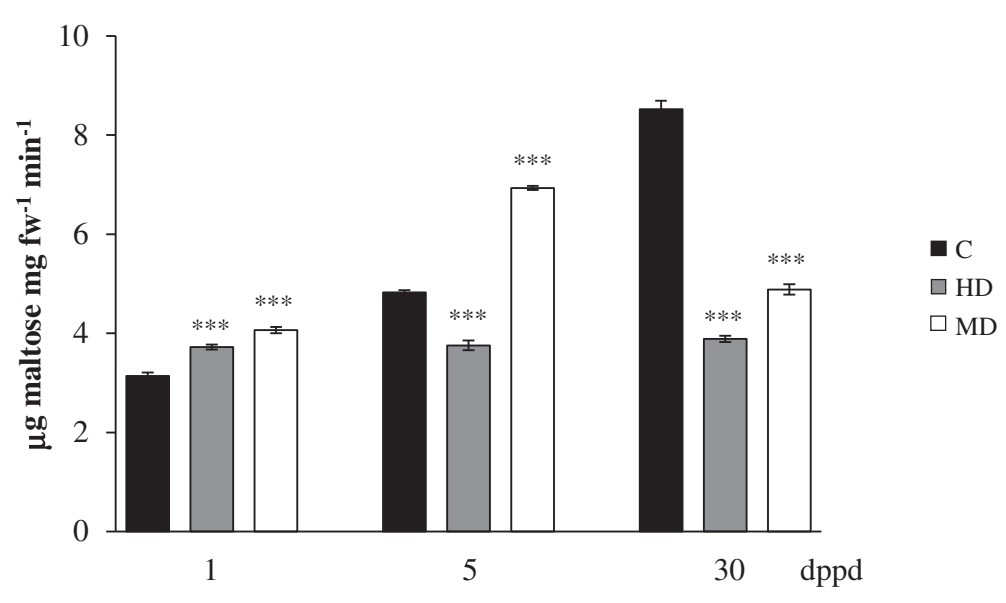

Figure 7 Amylolytic activity levels measured as $\mu \mathrm{g}$ of maltose per $\mathrm{mg}$ of fresh weight released per minute at different days post partial defoliation (dppd) in source leaves of intact control and defoliated Amaranthus cruentus plants. Defoliation was produced either by insect herbivory (HD) or mechanical damage (MD). For further details refer to Figure 1. 
strong in roots (Table 5). The strong induction of this gene detected in roots of both HD and MD plants at 5 dppd correlated with the transient accumulation of fatty acids detected in roots (Figure 8; Additional file 10). Such correlation was in agreement with the fact that PPTs are part of a known spectrum of plastidic phosphate translocators in non-photosynthetic plastids that deliver phosphoenolpyruvate (PEP) from the cytosol to plastids to support fatty acid biosynthesis via the action of pyruvate kinase $[97,98]$. In addition, the high expression this gene in leaves, at $5 \mathrm{dppd}$, could have been needed to import PEP into chloroplasts to support tissue recovery after damage [99].

Changes in the expression of a putative Kunitz protease inhibitor (AhKTI) and lipoxygenase (AhLOX2) genes as markers of the wound response and jasmonic acid signaling in partially defoliated $A$. cruentus.

The protease inhibitor AhKTI gene used as a marker of the wound response showed the expected rapid and stable induction in leaves in response to $\mathrm{HD}$ and $\mathrm{MD}$, as shown by a significant increase in expression at 1 and 5 dppd (Table 6). The stronger effect on AhKTI expression produced by HD was consistent with the differential expression of trypsin inhibitor activity produced in leaves of A. hypochondriacus plantlets subjected to mechanical wounding or herbivory [100]. The induction of this gene in unwounded tissues, such as roots of HD (at $1 \mathrm{dppd}$ ) and MD (at 5 dppd) plants, and stems of MD plants (which showed a biphasic pattern of expression at 1 and $30 \mathrm{dppd}$ ) further supports the generation of a yet undefined wound induced signal needed for the systemic expression of this and most other genes analyzed in this study. Defoliation also led to unexpectedly high levels of $A h K T I$ expression in panicles. Also interesting was the delayed down-regulation of $A h K T I$ observed at $30 \mathrm{dppd}$ in leaves of MD plants. In contrast, AtLOX2 used as a marker of JA synthesis, was predominantly expressed in leaves of HD plants, although altered expression of this gene was also detected in roots, where MD led to an early induction at $1 \mathrm{dppd}$, whereas HD repressed it (Table 6). A clear repression of this gene was detected in stems of both HD and MD plants at $5 \mathrm{dppd}$. The high expression of the AhLOX2 gene in leaves of HD plants was somehow expected considering the well-established spike in JA levels that is usually produced when plants are attacked by leaf chewing herbivores in order to induce resistance or tolerance responses [101-103]. Moreover, high AtLOX2 expression in leaves of HD plants, presumably leading to augmented JA levels, could have been a factor influencing the noticeable difference between gene expression between $\mathrm{HD}$ and MD plants observed in this study. Insect herbivory might have also impacted the stress signaling network through its effect on reactive oxygen species (ROS) synthesis and cellular redox metabolism [104]. Likewise, the possible role of JA as a systemic signal for the distal induction of genes in HD plants is in agreement with data generated in $A$. hypochondriacus showing that jasmonates can modulate defense responses vs. insects $[8,100]$ and strongly induce the systemic expression of various herbivory-responsive genes including $A O C$, a JA biosynthetic gene [105]. It is important to notice that JA can also induce changes in resource allocation to enhance plant tolerance to defoliation [101,106-108]. However, the proposed signaling role of JA in resistance/ tolerance responses in grain amaranth remains to be determined.

Different responses to insect herbivory and mechanical damage have been frequently reported in plants and are attributed to the inability to simulate insect herbivory by mechanical means, which often underestimate the damage produced by insect feeding. Moreover, instantaneous removal of leaf tissue by mechanical means is markedly

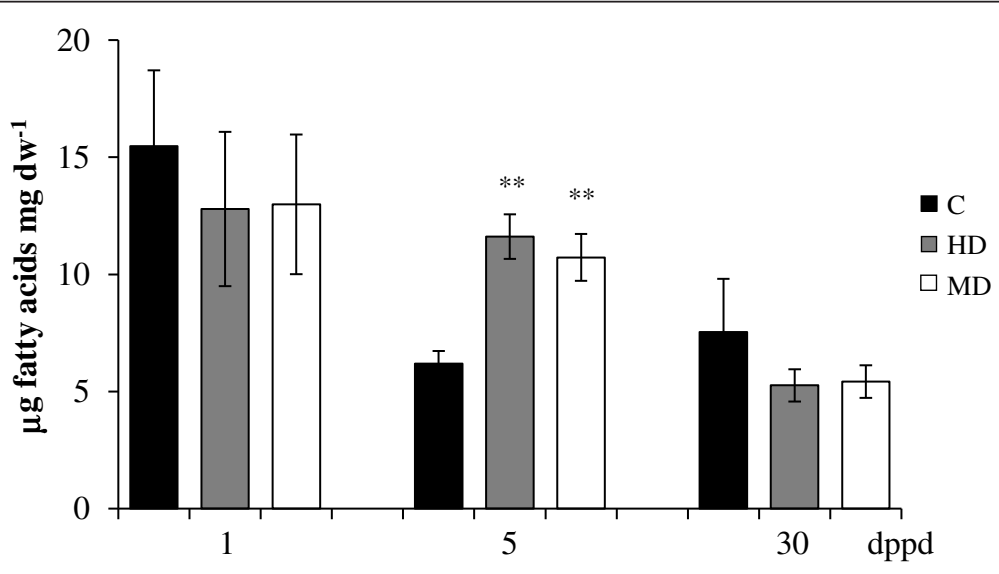

Figure 8 Total fatty acid levels in $\mu \mathrm{g}$ of fatty acids per $\mathrm{mg}$ of dry weight measured at different days post partial defoliation (dppd) in roots of intact control and defoliated Amaranthus cruentus plants. Defoliation was produced either by insect herbivory (HD) or mechanical damage (MD). For further details refer to Figure 1. 
different from the slower tissue removal caused by insect mandibles. Other subtle effects not generally recognized can be caused by trampling, defecating or the dispersal of pathogens by the herbivore [28], whereas a welldefined determinant of response differentiation is the insect's saliva. In this respect, it has been amply demonstrated that resistance signaling is elicited differently from simple wounding when herbivore-specific elicitors (e.g. fatty acid conjugates such as volicitin) contained in the insect's saliva or oral secretions are introduced into wounds [109-112].

\section{Changes in the expression of a senescence associated (AhSAG) gene as a marker of ageing and development in partially defoliated in $A$. cruentus}

The expression of the AhSAG gene, used as a marker of development and senescence, produced the expected pattern in leaves of HD plants, where a reduction/repression of its expression at $1 \mathrm{dppd}$ was followed by clearly augmented levels at 5 and 30 dppd (Table 6). A similar tendency, although weaker, was observed in leaves and stems MD plants, whereas in stems of HD plants, the expression of the AhSAG gene was strongly repressed. The early expression in roots of $\mathrm{HD}$ and MD plants at 1 dppd suggests that this gene may be a systemic marker of wound stress and not development, in this tissue. This is supported by several reports showing that several genes that are up-regulated during senescence also accumulate in response to biotic and abiotic stress [113]. Panicles of HD plants showed a very high expression of this gene. This was probably reflecting the accelerated onset of the flowering stage consistently observed in HD plants (results not shown). The differential effect of $\mathrm{HD}$ and $\mathrm{MD}$ on gene expression was again evidenced in stems, where a clearly contrasting effect on the expression of AhSAG was observed at $30 \mathrm{dppd}$.

In addition to early flowering, HD reduced leaf longevity and increased branching (data not shown). These changes, however, did not negatively affect plant height or seed yield in physiologically mature plants (data not shown). These changes indicate that insect herbivory produced a stronger ontogenetic shift than mechanical wounding in grain amaranth. The difference was manifested by premature flowering (an escape strategy?) and the accelerated senescence of mature leaves. This is in partial agreement with a related study that found that clipping in A. cruentus produced drastic changes in plant architecture, and led to an overcompensation response that increased seed yield [17].

\section{Conclusions}

Grain amaranth plants are known to thrive under harsh ambient conditions that are inhospitable to other crops, particularly cereals. The mechanisms responsible for drought and saline stress resistance have been attributed to several physiological, biochemical and/ or genetic adaptations, including superior water use efficiency, changes in root length and architecture, the accumulation of compatible solutes and/ or the expression of key stress-related genes [30]. Conversely, not much is known regarding the observed ability of grain amaranth to sustain defoliation. The NSC data obtained in this work showed that a single defoliation event in young grain amaranth plantlets led to a rapid reduction in NSC levels in both sink tissues and source leaves that recovered some time after defoliation. We propose that the rapid mobilization of foliar starch reserves followed by an efficient recovery of all NSC reserves supported the tolerance response to defoliation in grain amaranth, as manifested by unaltered plant growth and reproductive fitness. Moreover, the long-term sequestration of starch in roots and stems that was observed when the starch levels in leaves were unusually high, together with the temporary accumulation of fatty acids in roots, suggest a plastic response to defoliation in grain amaranth. Remarkably, only a few changes in gene expression and enzyme activity could be associated with the above changes. This outcome was in agreement with the highly complex nature of the $\mathrm{CHO}$ metabolic flux in plants, over which individual genes are predicted to have only a limited influence, if any. Also large differences in gene expression patterns were observed between HD and MD plants, even though the responses of plants to both treatments were very similar. This could have been associated with the stronger ontogenetic shift caused insect herbivory, which was manifested by premature flowering, altered plant architecture and accelerated leaf senescence.

In accordance with this and other related studies, it can be concluded that a better understanding of how $\mathrm{C}$ partitioning influences tolerance to defoliation, and perhaps to other stresses including excessive salinity [36], has a great potential for use in the future improvement of cultivated crops, particularly those that are stress and defoliation intolerant, such as maize.

\section{Methods}

Plant material, insects and treatments

Seeds of the two genotypes employed in this study, Amaranthus cruentus cultivar "Tarasca" and Amaranthus hypochondriacus cultivar "Revancha", were kindly provided by Eduardo Espitia (INIFAP, México). Seeds were germinated as described previously [30]. Larvae of the Hawaiian beet webworm Spoladea recurvalis, a common pest of amaranth and related species, were reared in a colony established from specimens collected in nearby fields. The seedlings were subsequently 
transplanted to $16 \mathrm{~L}$ plastic pots, containing sterile general soil mixture, 21 days after germination, and were transported to a greenhouse where the experiments were conducted. The plantlets were fertilized once, one week after transplant, with a 20: 10: $20(\mathrm{~N}: \mathrm{P}: \mathrm{K})$ nutrient soil drench solution according to the manufacturer's instructions (Peters Professional; Scotts-Sierra Horticultural Products, Marysville, OH, USA) until they had 6 to 8 expanded leaves. All herbivory experiments were performed with 30-days-old $A$. cruentus plants in a greenhouse localized at Cinvestav-Irapuato, México, $\left(20^{\circ}\right.$ $\left.40^{\prime} 18^{\prime \prime} \mathrm{N} 101^{\circ} 20^{\prime} 48^{\prime \prime} \mathrm{W}\right)$ under natural conditions of light and temperature. The choice of A. cruentus for the defoliation experiments was based on its insensitivity to the photo-period, a useful characteristic which allowed extended experimentation during early and late periods of the year, which are unsuitable for A. hypochondriacus [12]. Defoliation by insect herbivory was performed by placing three larvae per plant for 4 days, which resulted in a leaf tissue loss of approximately $30 \%$. Defoliation by mechanical damage was performed by removing the same percentage of foliar tissue with a $0.5 \mathrm{~cm}$ diameter cork-borer. Care was exercised to match the pattern of mechanical tissue removal with that of herbivory. Samples of damaged source leaves (three per plant), stem (15 cm segments, starting from the base) and roots were collected from three plants at $0,1,5$ and 30 days after the defoliation treatment. Panicles were sampled soon after their emergence, 30 days after treatment. Control experiments with undamaged plants were performed simultaneously. Plant height and total number of leaves were measured at the three time points. The number of internodes per stem was determined at $30 \mathrm{dppd}$. In two experiments, seeds were harvested from groups of control and defoliated plants allowed to reach full maturity ( $\geq 110 \mathrm{dppd}$ ). Tissue samples of each three plant group were pooled and were flash frozen with liquid $\mathrm{N}_{2}$ and stored at $-80^{\circ} \mathrm{C}$ until use. Pooled samples were used for analysis of NSC, fatty acids, gene expression and sucrolytic activity levels. Each experiment was repeated three times, once in the fall-winter of 2010 and twice in the spring of 2011.

Leaf tissue of intact $A$. hypochondriacus and A. cruentus plants was used for RNA extraction and genomic DNA extraction for full-length cDNA and gene isolation.

\section{Extraction of total RNA and CDNA preparation}

Total RNA was extracted from 100-200 mg of frozen tissue with the Trizol reagent (Invitrogen, Carlsbad, CA, USA), according to the manufacturer's instructions, with modifications. These consisted of the addition of a salt solution (sodium citrate $0.8 \mathrm{M}+1.2 \mathrm{M} \mathrm{NaCl}$ ) during precipitation in a $1: 1 \mathrm{v} / \mathrm{v}$ ratio with isopropanol and further purification with $\mathrm{LiCl}(8 \mathrm{M})$ for one hour at $4^{\circ} \mathrm{C}$. All RNA samples were analyzed by formaldehyde agarose gel electrophoresis and visual inspection of the ribosomal RNA bands upon ethidium bromide staining. Total RNA samples $(1 \mu \mathrm{g})$ were reverse-transcribed to generate the first-strand cDNA using an oligo $\mathrm{dT}_{20}$ primer and 200 units of SuperScript II reverse transcriptase (Invitrogen).

\section{Gene expression analysis by quantitative real-time RT-PCR (qRT-PCR)}

The cDNA employed for the qRT-PCR assays was initially prepared from $4 \mu \mathrm{g}$ total RNA. It was then diluted ten-fold in sterile deionized-distilled (dd) water prior to qRT-PCR. Amplifications were performed using SYBR Green detection chemistry and run in triplicate in 48well reaction plates with the StepOne ${ }^{\mathrm{Tw}}$ Real-Time PCR System (Applied Biosystems, Perkin-Elmer, Foster City, CA, USA). Reactions were prepared in a total volume of $8 \mu \mathrm{l}$ containing: $1 \mu \mathrm{l}$ of template, $0.8 \mu \mathrm{l}$ of each amplification primer $(2 \mu \mathrm{M}), 4 \mu \mathrm{l}$ of $\mathrm{SYBR}^{\circledR}{ }^{\circledR}$ Green JumpStart ${ }^{\mathrm{mat}}$ Taq Ready Mix $^{\text {Tm }}$ (Sigma-Aldrich St. Louis, MO, USA) and $1.4 \mu \mathrm{l}$ of sterile dd water. Quantitative real-time PCR was performed in triplicate for each sample using the primers listed in Additional file 11. Primers were designed for each gene, based on partial cDNA sequences derived from the transcriptomic analysis of $A h$ [30] or from complete cDNAs generated in this study (see above). Primer design was performed using DNA calculator software (Sigma-Aldrich) and included, when possible, part of unique 3' non-coding regions to ensure specificity.

The following protocol was followed for all qRT-PCR runs: $15 \mathrm{~min}$ at $95^{\circ} \mathrm{C}$ to activate the JumpStart ${ }^{\mathrm{Tm}} \mathrm{Taq}$ Polymerase (Sigma-Aldrich), followed by 40 cycles of denaturation at $95^{\circ} \mathrm{C}$ for $15 \mathrm{~s}$ and annealing at $60^{\circ} \mathrm{C}$ for 1 min. Slow amplifications requiring an excess of 32 cycles were not considered for analysis. The specificity of the amplicons was verified by melting curve analysis after 40 cycles and agarose gel electrophoresis. Baseline and threshold cycles $(\mathrm{Ct})$ were automatically determined using Real-Time PCR System software. PCR efficiencies for all genes tested were greater than $95 \%$. Relative expression was calculated using the comparative cycle threshold method [114], where delta $(\Delta)$ cycle threshold of cDNA from undamaged controls was defined as 100\% transcript presence.

Transcript abundance data were normalized against the average transcript abundance of three reference genes: actin (isotig 10321), $\beta$-tubulin (isotig 05486) and elongation factor $1 \alpha$ (EF1 $\alpha$ ) (isotig 13098). These were obtained from the above transcriptomic study. The fold change in expression of the target genes in each treatment was calculated using the following equation: 
$2^{-\Delta \Delta \mathrm{Ct}}$, where $\Delta \Delta \mathrm{Ct}=(\mathrm{Ct}$ target gene - average $\mathrm{Ct}$ reference genes $)_{\text {treatment }}$ - $(\mathrm{Ct}$ target gene - average $\mathrm{Ct}$ refer-

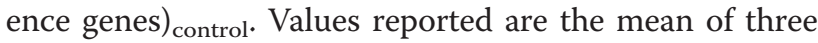
repetitions $\pm \mathrm{SE}$ of one representative experiment. The qRT-PCR expression analysis of the majority of the genes included in this study, except for all sucrolytic, $A G P$ and invertase inhibitor genes that were previously shown to have reproducible patterns of expression by semi-quantitative RT-PCR assays (not shown), was validated in at least two independent experiments.

\section{Full-length cDNA amplification}

In order to amplify full-length $A h S u S-1, A h S u S-2$, AhAGPS-1, AhA/NI-1 and AhVI-1 cDNAs, total RNA samples $(1 \mu \mathrm{g})$ from leaves of grain amaranth plantlets were reverse-transcribed to generate the first-strand cDNA as described above. An aliquot of these reactions $(2 \mu \mathrm{l})$ was then directly used as template in all PCR reactions in the presence of 100 pmol each of specific primers designed on the basis of sequences obtained from the $A h$ transcriptome [30] (see Additional file 12). The fragments obtained were cloned and sequenced to confirm that they corresponded to the gene of interest. The amplification of the 5' and 3' cDNA ends was carried out by RACE (Rapid Amplification of cDNA Ends) with the SMARTer $^{\mathrm{TM}}$ RACE cDNA Amplification Kit (Clontech, Laboratories, Mountain View, CA), according to the manufacturer's instructions. All complete cDNA sequences were deposited in the GenBank as JQ012918 (AhSuS-1), JQ012919 (AhSuS-2), JQ012920 (AhA/NI-1), JQ012921 (AhVI-1) and HM021763 (AhAGPS-1).

\section{PCR amplification of a partial CDNA sequences of cell wall invertase (AhCWI)}

Degenerate oligonucleotides OIN3 (5' CCTTCACYT NTTYTAYCARYAYAAYCC 3', [115] and INV5 $\left(5^{\prime} \mathrm{N}\right.$ GTCTTGGWDGCGTAAATAYTTMCCATA 3') were deduced from conserved cell wall invertase (CWI) sequences in Beta vulgaris (AJ278531), Chenopodium rubrum (X81792-94) and Daucus carota (M58362.1), and used as primers for PCR amplification. PCR reactions were performed in a $25 \mu$ l reaction volume with $2 \mu \mathrm{l}$ cDNA from A. hypochondriacus as template, primers (100 pmol each), dNTPs (100 mM each), $10 \times$ Taq reaction buffer, $50 \mathrm{mM} \mathrm{MgCl}_{2}$ and $1 \mathrm{U}$ of Taq polymerase (Invitrogen). After a pre-denaturing step at $94^{\circ} \mathrm{C}$ for $3 \mathrm{~min}$, the amplification consisted of 35 cycles of $30 \mathrm{~s}$ at $94^{\circ} \mathrm{C}, 30 \mathrm{~s}$ at $60^{\circ} \mathrm{C}$ and $45 \mathrm{~s}$ at $72^{\circ} \mathrm{C}$ and a final extension of $10 \mathrm{~min}$ at $72^{\circ} \mathrm{C}$. The resulting PCR fragments were separated and purified by agarose gel electrophoresis. The PCR fragments from the major bands were purified, cloned and sequenced.

\section{Full length genomic amplification}

Genomic DNA was extracted from leaves of A. hypochondriacus plantlets as instructed [116] and digested with four different restriction enzymes (DraI, EcoRV, PvuI, StuI). The resulting fragments were blunt-end ligated to the Genome-Walker Adaptor provided by the Genome-Walker kit (Clontech) to generate the corresponding libraries. These libraries were used as templates for PCR and nested PCR using primers (see Additional file 12) designed on the complete cDNAs for AhVI-1 and AhAGPS-1 obtained previously (see above). Amplifications were done in both $3^{\prime}$ and $5^{\prime}$ directions to obtain the complete sequences of these genes, including a sizeable portion of their promoter regions. The overlap between the genomic sequences thus obtained and their respective cDNA templates confirmed the identity of the newly generated fragments. All PCR amplicons obtained were cloned using the TOPO TA cloning kit (Invitrogen) and sequenced. Both AhVI-1 and AhAGPS-1 genomic sequences were deposited in the GenBank as JQ012921 and JQ034321, respectively.

\section{DNA sequencing and sequences analysis}

Recombinant plasmid DNA was prepared and then sequenced. Sequencing was provided as a service by the National Laboratory of Genomics for Biodiversity (Langebio, at Cinvestav- Irapuato) and the Biotechnology Institute (IBT-UNAM, México). Computer analysis was performed using FastPCR 6.0, AnnHyb 4.944 and Chromas-Lite 2.01 software. Sequence homologies were verified against GenBank databases using BLAST programs [117].

\section{Phylogenetic analyses}

Alignment of amino acid sequences and phylogenetic analyses were conducted using the PhyML method within the Bosque 1.7.157 software.

\section{Putative sub-cellular localization}

Putative sub-cellular localization of the genes was performed in silico by the following programs, available online: PSORT, SignalP, TargetP, Protein Prowler and MitoProt. (psort.hgc.jp/form.html, www.cbs.dtu.dk/services/TargetP/, pprowler.imb.uq.edu.au/, www.cbs.dtu.dk/services/SignalP/ and ihg.gsf.de/ihg/mitoprot.html).

\section{Bio-informatic analysis}

The promoter sequences of the AhVI-1 and AhAGPS-1 genes were subjected to an in silico analysis with the following databases: PLACE (www.dna.affrc.go.jp/PLACE/), PlantCARE (http://bioinformatics.SlPSb.ugent.be/wetools/ plantcare/html/), the SolGenomics Network (solgenomics. net) and the Genomatix software suite (www.genomatix.de) in order to identify the presence of putative cis-regulatory elements. 


\section{Determination of non-structural carbohydrate levels}

All tissues (leaves, stems, roots and panicles) were collected at the beginning of the dark period (6:30 p.m.) and flash frozen in liquid nitrogen. Frozen ground tissue (200 mg) was extracted with $500 \mu \mathrm{l} 80 \%$ aqueous ethanol $(\mathrm{v} / \mathrm{v})$ and incubated at $4^{\circ} \mathrm{C}$ for $10 \mathrm{~min}$ with stirring. After refrigerated centrifugation at $10,000 \mathrm{rpm}\left(4^{\circ} \mathrm{C}\right.$ for $\left.10 \mathrm{~min}\right)$, the cleared supernatants were transferred into new tubes and concentrated by centrifugation (Heto Maxi Dry Lyo, Heto-Holten, Denmark). The residue was re-dissolved in $500 \mu \mathrm{l}$ of $100 \mathrm{mM}$ Hepes buffer, pH 7.4, and $5 \mathrm{mM} \mathrm{MgCl}_{2}$, and used for the determination de soluble sugars. The pellet derived from the centrifugation step was used for the determination of starch. To this end, it was homogenized with $500 \mu \mathrm{l}$ of $10 \mathrm{mM} \mathrm{KOH}$ and incubated at $99^{\circ} \mathrm{C}$ for two hours. Sucrose (SUC), glucose (GLC), fructose (FRC) and starch contents were measured using enzyme-based methods as instructed (Boehringer Mannheim/R-Biopharm, Darmstadt, Germany), except that the final reaction volume was reduced to fit a micro-plate format $(250 \mu \mathrm{l}$ per reaction).

\section{Determination of fatty acid levels}

Fatty acids were determined according to [118] with modifications: i) the methylation step was performed with $\mathrm{BF}_{3}$ at slightly harsher conditions $\left(100^{\circ} \mathrm{C}\right.$ for $15 \mathrm{~min}$ ), and ii) the organic phase was dried under a stream of $\mathrm{N}_{2}$ and re-dissolved in isooctane before loading into the gas chromatograph.

Invertase, sucrose synthase and amylase activities in vitro Acid soluble (vacuolar) and insoluble (cell wall), neutral (cytoplasmic) invertase and sucrose synthase activities were determined according to $[119,120]$. Total amylolytic activity was determined as described in [121].

\section{Statistical analysis}

The statistical analysis of the data was performed in the R statistical language (R Development Core Team 2004, Version 1.9.0; http://www.R-project.org).

\section{Additional files}

Additional file 1: Characteristics of the grain amaranth genes selected for analysis in different tissues of defoliated plants to determine their possible role in $\mathrm{C}$ mobilization and tolerance.

Additional file 2: Comparison of deduced amino acid sequences of plant sucrose synthases.

Additional file 3: Comparison of deduced amino acid sequences of plant invertases.

Additional file 4: Comparison of deduced amino acid sequences of plant ADP-glucose pyrophosphorylases (AGP).

Additional file 5: Phylogenetic dendogram of known plant invertase inhibitors.
Additional file 6: Structure of grain amaranth genes coding for a small subunit of ADP glucose pyrophosphorylase (AhAGPS-1) and a vacuolar invertase (AhVI-1).

Additional file 7: Regulatory elements identified in the promoter regions of the AhAGPS-1 and AhVI-1 genes. The 5' regulatory region was analyzed using PLACE, PlantCARE and Genomatix Matinspector databases.

Additional file 8: Comparison of the $5^{\prime}$ regulatory regions identified in the ADP-glucose pyrophosphorylase and vacuolar invertase genes of Solanum tuberosum, S. lycopersicum, Beta vulgaris and Amaranthus hypochondriacus.

Additional file 9: Results of an atypical experiment showing a longterm accumulation of starch in stems and roots of MD plants.

Additional file 10: Fatty acid composition in roots of control and defoliated grain amaranth plants.

Additional file 11: Primers used for gene expression analysis by qRT PCR.

Additional file 12: Primers used to amplify the 5 'and 3' cDNA ends (RACE) and the genomic sequences, including part of the promoter regions, of the AhVI-1 and AhAGPS-1 genes.

\section{Competing interests}

The authors declare that they have no competing interests.

\section{Authors' contributions}

JPDF designed and coordinated the study. PACA performed all the experiments. She was aided by HAA in statistics and genomics and by NAMG in the metabolite and enzymatic assays. PACA and JPDF analyzed the data. ATF helped with the Real-Time PCR method. JPDF and ATF wrote the manuscript. All authors read and approved the final version of the manuscript.

\section{Acknowledgements}

This work was largely supported financially by the European Commission 6th Framework Programme, AMARANTH: FUTURE-FOOD, Contract No. 032263. Financial support by México Tierra de Amaranto A. C. and The Deborah Presser-Velder Foundation is also acknowledged. PACA and HAA were supported by postgraduate scholarships (codes 228820 and 191369, respectively) granted by The National Council for Science and Technology (CONACyT, México).

\section{Author details}

${ }^{1}$ Unidad de Biotecnología e Ingeniería Genética de Plantas

(Cinvestav-Irapuato), Km 9.6 del Libramiento Norte Carretera Irapuato-León, Apartado Postal 629, C.P. 36821 Irapuato, Gto, México. ${ }^{2}$ Present address: Instituto de Biotecnología, Facultad de Ciencias Biológicas, Universidad Autónoma de Nuevo León, Av. Pedro de Alba y Manuel L. Barragán s/n, Ciudad Universitaria, C.P. 66450 San Nicolás de los Garza, Nuevo León, México.

Received: 22 June 2012 Accepted: 3 September 2012 Published: 12 September 2012

\section{References}

1. Flowers TJ, Colmer TD: Salinity tolerance in halophytes. New Phytol 2008, 179:945-963.

2. Akubugwo IE, Obasi NA, Chinyere GC, Ugbogu AE: Nutritional and chemical value of Amaranthus hybridus L. leaves from Afikpo, Nigeria. Afr J Biotechnol 2007, 6:2833-2839.

3. Brenner D, Baltensperger D, Kulakow P, Lehmann J, Myers R, Slabbert M, Sleugh B: Genetic resources and breeding of Amaranthus. Plant Breed Rev 2000, 19:227-285.

4. Huerta-Ocampo J, Barba de la Rosa A: Amaranth: a pseudo-cereal with nutraceutical properties. Curr Nutr Food Sci 2011, 7:1-9.

5. Johnson $\mathrm{BL}$, Henderson $\mathrm{TL}$ : Water use patterns of grain amaranth in the northern Great Plains. Agron J 2002, 94:1437-1443. 
6. Omami EN, Hammes PS, Robbertse PJ: Differences in salinity tolerance for growth and water-use efficiency in some amaranth (Amaranthus spp.) genotypes. New Zeal J Crop Hort 2006, 34:11-22

7. Aragón-García A, Huato MAD, Lara MH, Sáenz-de-Cabezón F, Pérez-Moreno I, Marco-Mancebón V, López-Olguín JF: Insect occurrence and losses due to phytophagous species in the amaranth Amaranthus hypocondriacus L. crop in Puebla, Mexico. Afr J Agr Res 2011, 6:5924-5929.

8. Délano-Frier JP, Martínez-Gallardo NA, Martínez-de la Verga O, Salas-Araiza MD, Barbosa-Jaramillo ER, Torres A, Vargas P, Borodanenko A: The effect of exogenous jasmonic acid on induced resistance and productivity in amaranth (Amaranthus hypochondriacus) is influenced by environmental conditions. J Chem Ecol 2004, 30:1001-1034.

9. Gassmann AJ: Effect of photosynthetic efficiency and water availability on tolerance of leaf removal in Amaranthus hybridus. J Ecol 2004, 92:882-892.

10. Weaver SE, Mcwilliams EL: The biology of Canadian weeds .44. Amaranthus retroflexus L., A. powellii S. Wats and A. hybridus L. Can J Plant Sci 1980, 60:1215-1234.

11. Grubben $\mathrm{GJH}$ : The cultivation of amaranth as a tropical leaf vegetable with special reference to South Dahomey. Amsterdam: Department of Agricultural Research, Royal Tropical Institute; 1976.

12. Espitia-Rangel E, Mapes-Sánchez C, Escobedo-López D, de la O-Olán M, Rivas-Valencia P, Martínez-Trejo G, Cortés-Espinosa L, Hernández-Casillas JM: Conservación y uso de los recursos genéticos de amaranto en México. Celaya, Guanajuato, México: SINAREFI-INIFAP-UNAM, Centro de Investigación Regional Centro; 2010.

13. Weber LE, Irwin MD, Baltensperger DD, Applegate WW, Lehmann JW, Putnam DH: Amaranth-grain production guide. Emmaus, PA: Rodale Press; 1990.

14. Wilson RL: Studies of insects feeding on grain amaranth in the Midwest. J Kansas Entomol Soc 1989, 62:440-448.

15. Fomsgaard I, Añon M, Barba de la Rosa A, Christophersen C, Dusek K, Délano- Frier J, Espinoza Pérez J, Fonseca A, Janovská D, Kudsk P, Labouriau R, Lacayo-Romero M, Martínez N, Matus F, Matusová K, Mathiassen S, Noellemeyer E, Pedersen H, Stavelikova H, Steffensen S, de Troiani R, Taberner A: Adding Value to Holy Grain: Providing the Key Tools for the Exploitation of Amaranth - the Protein-rich Grain of the Aztecs. Results from a Joint European - Latin American Research Project. Denmark: Department of Integrated Pest Management, Aarhus University, Faculty of Agricultural Sciences; 2010

16. Vargas-Ortiz E: Estudio de la redistribución de carbohidratos y nitrógeno como posible mecanismo de tolerancia a pérdida de tejido foliar por herbivoría y/o daño mecánico en amaranto. MSc thesis.: Cinvestav-Unidad Irapuato, Departamento de Biotecnología y Bioquímica; 2009.

17. Martínez-Moreno D, Nuñez-Farfán J, Terrazas T, Muiz LD, Trinidad-Santos A, Trejo C, Larque-Saavedra A: Plastic responses to clipping in two species of Amaranthus from the Sierra Norte de Puebla, Mexico. Genet Resour Crop Ev 1999, 46:225-234

18. Bruce TJ, Pickett JA: Plant defence signalling induced by biotic attacks. Curr Opin Plant Biol 2007, 10:387-392.

19. Howe GA, Jander G: Plant immunity to insect herbivores. Annu Rev Plant Biol 2008, 59:41-66.

20. Nuñez-Farfán J, Fornoni J, Valverde PL: The evolution of resistance and tolerance to herbivores. Annu Rev Ecol Evol S 2007, 38:541-566

21. Schwachtje J, Baldwin IT: Why does herbivore attack reconfigure primary metabolism? Plant Physio/ 2008, 146:845-851.

22. Stowe KA, Marquis RJ, Hochwender CG, Simms EL: The evolutionary ecology of tolerance to consumer damage. Annu Rev Ecol Syst 2000, 31:565-595.

23. Farrar JF: Sink strength: what is it and how do we measure it? Plant Cell Environ 1993, 16:1015.

24. McCormick AJ, Cramer MD, Watt DA: Sink strength regulates photosynthesis in sugarcane. New Phytol 2006 171:759-770.

25. Paul MJ, Pellny TK: Carbon metabolite feedback regulation of leaf photosynthesis and development. J Exp Bot 2003 54:539-547.

26. Rolland F, Baena-Gonzalez E, Sheen J: Sugar sensing and signaling in plants: conserved and novel mechanisms. Annu Rev Plant Physiol 2006, 57:675-709.
27. McCormick AJ, Cramer MD, Watt DA: Changes in photosynthetic rates and gene expression of leaves during a source-sink perturbation in sugarcane. Ann Bot 2008, 101:89-102.

28. Baldwin IT: Herbivory simulations in ecological research. Trends Ecol Evol 1990, 5:91-93

29. Lethilä K, Bolt E: The use and usefulness of artificial herbivory in plantherbivore studies. In Ecological Studies. Edited by Wiesser WW SE. Berlin Heidelberg: Springer-Verlag; 2004:257-273.

30. Délano-Frier JP, Avilés-Arnaut H, Casarrubias-Castillo K, Casique-Arroyo G, Castrillón-Arbeláez PA, Herrera-Estrella L, Massange-Sánchez J, MartínezGallardo NA, Parra-Cota Fl, Vargas-Ortiz E, Estrada-Hernández MG: Transcriptomic analysis of grain amaranth (Amaranthus hypochondriacus) using 454 pyrosequencing: comparison with $\mathrm{A}$. tuberculatus, expression profiling in stems and in response to biotic and abiotic stress. BMC Genomics 2011, 12:363.

31. Klotz KL, Haagenson DM: Wounding, anoxia and cold induce sugarbeet sucrose synthase transcriptional changes that are unrelated to protein expression and activity. J Plant Physiol 2008, 165:423-434.

32. Vargas WA, Pontis HG, Salerno GL: Differential expression of alkaline and neutral invertases in response to environmental stresses: characterization of an alkaline isoform as a stress-response enzyme in wheat leaves. Planta 2007, 226:1535-1545.

33. Xiang L, Le Roy K, Bolouri-Moghaddam MR, Vanhaecke M, Lammens W, Rolland F, Van den Ende W: Exploring the neutral invertase-oxidative stress defence connection in Arabidopsis thaliana. J Exp Bot 2011, 62:3849-3862

34. Gonzalez MC, Roitsch T, Cejudo FJ: Circadian and developmental regulation of vacuolar invertase expression in petioles of sugar beet plants. Planta 2005, 222:386-395.

35. Ohyama A, Nishimura S, Hirai M: Cloning of cDNA for a cell wall-bound acid invertase from tomato (Lycopersicon esculentum) and expression of soluble and cell wall-bound invertases in plants and wounded leaves of L. esculentum and L. peruvianum. Genes Genet Syst 1998, 73:149-157.

36. Yin YG, Kobayashi Y, Sanuki A, Kondo S, Fukuda N, Ezura H, Sugaya S, Matsukura C: Salinity induces carbohydrate accumulation and sugarregulated starch biosynthetic genes in tomato (Solanum lycopersicum L. cv. 'Micro-Tom') fruits in an ABA- and osmotic stress-independent manner. J Exp Bot 2010, 61:563-574.

37. Kwak MS, Min SR, Lee SM, Kim KN, Liu JR, Paek KH, Shin JS, Bae JM: A sepalexpressed ADP-glucose pyrophosphorylase gene (NtAGP) is required for petal expansion growth in 'Xanthi' tobacco. Plant Physiol 2007, 145:277-289.

38. Adhikari TB, Balaji B, Breeden J, Goodwin SB: Resistance of wheat to Mycosphaerella graminicola involves early and late peaks of gene expression. Physiol Mol Plant P 2007, 71:55-68.

39. Weigelt $K$, Kuster $H$, Rutten T, Fait A, Fernie AR, Miersch O, Wasternack C, Emery RJ, Desel C, Hosein F, Muller M, Saalbach I, Weber H: ADP-glucose pyrophosphorylase-deficient pea embryos reveal specific transcriptional and metabolic changes of carbon-nitrogen metabolism and stress responses. Plant Physiol 2009, 149:395-411.

40. Rausch T, Greiner S: Plant protein inhibitors of invertases. Biochim Biophys Acta 2004, 1696:253-261.

41. Castrillón-Arbeláez PA, Délano-Frier JP: The sweet side of inhibition invertase inhibitors and their importance in plant development and stress responses. Curr Enz Inhib 2011, 7:169-177.

42. Sturm A, Chrispeels MJ: cDNA cloning of carrot extracellular betafructosidase and its expression in response to wounding and bacterialinfection. Plant Cell 1990, 2:1107-1119.

43. Downie SR, Katz-Downie DS, Cho KJ: Relationships in the caryophyllales as suggested by phylogenetic analyses of partial chloroplast DNA ORF2280 homolog sequences. Am J Bot 1997, 84:253-273.

44. Ray T, Roy SC: Phylogenetic relationships between members of Amaranthaceae and Chenopodiaceae of lower Gangetic plains using RAPD and ISSR markers. Bangladesh J Bot 2007, 36:21-28.

45. Nakata PA, Anderson JM, Okita TW: Structure and expression of the potato ADP-glucose pyrophosphorylase small subunit. J Biol Chem 1994, 269:30798-30807.

46. Müller-Rober B, Nast G, Willmitzer L: Isolation and expression analysis of cDNA clones encoding a small and a large subunit of ADP-glucose pyrophosphorylase from sugar beet. Plant Mol Biol 1995 27:191-197. 
47. Bieniawska Z, Barratt DHP, Garlick AP, Thole V, Kruger NJ, Martin C, Zrenner $R$, Smith AM: Analysis of the sucrose synthase gene family in Arabidopsis. Plant J 2007, 49:810-828.

48. Godt DE, Riegel A, Roitsch T: Regulation of sucrose synthase expression in Chenopodium rubrum: characterization of sugar induced expression in photoautotrophic suspension cultures and sink tissue specific expression in plants. J Plant Physiol 1995, 146:231-238.

49. Haagenson DM, Klotz KL, McGrath JM: Sugarbeet sucrose synthase genes differ in organ-specific and developmental expression. J Plant Physiol 2006, 163:102-106.

50. Komatsu A, Moriguchi T, Koyama K, Omura M, Akihama T: Analysis of sucrose synthase genes in citrus suggests different roles and phylogenetic relationships. J Exp Bot 2002, 53:61-71.

51. Hesse $H$, Willmitzer $L$ : Expression analysis of a sucrose synthase gene from sugar beet (Beta vulgaris L.). Plant Mol Biol 1996, 30:863-872.

52. Subbaiah CC, Palaniappan A, Duncan K, Rhoads DM, Huber SC, Sachs MM: Mitochondrial localization and putative signaling function of sucrose synthase in maize. J Biol Chem 2006, 281:15625-15635

53. Sturm A, Hess D, Lee HS, Lienhard S: Neutral invertase is a novel type of sucrose-cleaving enzyme. Physiol Plant 1999, 107:159-165.

54. Vargas WA, Pontis HG, Salerno GL: New insights on sucrose metabolism: evidence for an active $\mathrm{A} / \mathrm{N}$-Inv in chloroplasts uncovers a novel component of the intracellular carbon trafficking. Planta 2008, 227:795-807.

55. Nonis A, Ruperti B, Pierasco A, Canaguier A, Adam-Blondon AF, Di Gaspero $G$, Vizzotto G: Neutral invertases in grapevine and comparative analysis with Arabidopsis, poplar and rice. Planta 2008, 229:129-142.

56. Huang LF, Bocock PN, Davis JM, Koch KE: Regulation of invertase: a suite of transcriptional and post-transcriptional mechanisms. Funct Plant Biol 2007, 34:499-507.

57. Rae AL, Casu RE, Perroux JM, Jackson MA, Grof CPL: A soluble acid invertase is directed to the vacuole by a signal anchor mechanism. J Plant Physiol 2011, 168:983-989.

58. Maas C, Laufs J, Grant S, Korfhage C, Werr W: The combination of a novel stimulatory element in the first exon of the maize Shrunken-1 gene with the following intron 1 enhances reporter gene expression up to 1000fold. Plant Mol Biol 1991, 16:199-207.

59. Ruan YL, Jin Y, Yang YJ, Li GJ, Boyer JS: Sugar input, metabolism, and signaling mediated by invertase: roles in development, yield potential, and response to drought and heat. Mol Plant 2010, 3:942-955.

60. Zhu $Y$, Cai $X L$, Wang $Z Y$, Hong MM: An interaction between a MYC protein and an EREBP protein is involved in transcriptional regulation of the rice $W x$ gene. J Biol Chem 2003, 278:47803-47811.

61. Alberto F, Bignon C, Sulzenbacher G, Henrissat B, Czjzek M: The threedimensional structure of invertase (beta-fructosidase) from Thermotoga maritima reveals a bimodular arrangement and an evolutionary relationship between retaining and inverting glycosidases. $J \mathrm{Bio} / \mathrm{Chem}$ 2004, 279:18903-18910.

62. Bocock PN, Morse AM, Dervinis C, Davis JM: Evolution and diversity of invertase genes in Populus trichocarpa. Planta 2008, 227:565-576.

63. Pons T, Olmea O, Chinea G, Beldarrain A, Marquez G, Acosta N, Rodriguez L, Valencia A: Structural model for family 32 of glycosyl-hydrolase enzymes. Proteins 1998, 33:383-395.

64. Huber SC: Relationship between photosynthetic starch formation and dry-weight partitioning between the root and shoot. Can J Bot 1983, 61:2709-2716.

65. Orians CM, Thorn A, Gomez S: Herbivore-induced resource sequestration in plants: why bother? Oecologia 2011, 167:1-9.

66. Barry KM, Quentin A, Eyles A, Pinkard EA: Consequences of resource limitation for recovery from repeated defoliation in Eucalyptus globulus Labilladiere. Tree Physio/ 2012, 32:24-35.

67. Kosola KR, Dickmann DI, Paul EA, Parry D: Repeated insect defoliation effects on growth, nitrogen acquisition, carbohydrates, and root demography of poplars. Oecologia 2001, 129:65-74.

68. Palacio S, Hester AJ, Maestro M, Millard P: Browsed Betula pubescens trees are not carbon-limited. Funct Ecol 2008, 22:808-815.

69. Palacio S, Paterson E, Sim A, Hester AJ, Millard P: Browsing affects intraring carbon allocation in species with contrasting wood anatomy. Tree Physiol 2011, 31:150-159.

70. Tschaplinski TJ, Blake TJ: Carbohydrate mobilization following shoot defoliation and decapitation in hybrid poplar. Tree Physiol 1994, 14:141-151.
71. Lee JM, Sathish P, Donaghy DJ, Roche JR: Plants modify biological processes to ensure survival following carbon depletion: a Lolium perenne model. PLOS ONE 2010, 5:e12306.

72. Caldwell MM, Richards JH, Johnson DA, Nowak RS, Dzurec RS: Coping with herbivory: photosynthetic capacity and resource allocation in two semiarid Agropyron bunchgrasses. Oecologia 1981, 50:14-24.

73. Rivera-Solís G, Abdala-Roberts L, Cervera JC, Parra-Tabla V, Ruiz-Ruiz J, Betancur-Ancona D: Mechanisms and traits associated with compensation for defoliation in Ruellia nudiflora. Plant Ecol 2012, 213:303-314.

74. Fang XW, Li JH, Xiong YC, Xu DH, Fan XW, Li FM: Responses of Caragana korshinskii Kom. to shoot removal: mechanisms underlying regrowth. Ecol Res 2008, 23:863-871.

75. Taliercio EW, Chourey PS: Post-transcriptional control of sucrose synthase expression in anaerobic seedlings of maize. Plant Physiol 1989, 90:1359-1364

76. Barrero-Sicilia C, Hernando-Amado S, Gonzalez-Melendi P, Carbonero P. Structure, expression profile and subcellular localisation of four different sucrose synthase genes from barley. Planta 2011, 234:391-403.

77. Baud S, Vaultier MN, Rochat C: Structure and expression profile of the sucrose synthase multigene family in Arabidopsis. J Exp Bot 2004, 55:397-409.

78. Koch K: Sucrose metabolism: regulatory mechanisms and pivotal roles in sugar sensing and plant development. Curr Opin Plant Biol 2004, 7:235-246.

79. Rojo E, Zouhar J, Carter C, Kovaleva V, Raikhel NV: A unique mechanism for protein processing and degradation in Arabidopsis thaliana. Proc Natl Acad Sci USA 2003, 100:7389-7394.

80. Zhang HJ, Dong SM, Wang MF, Wang W, Song WW, Dou XY, Zheng XB, Zhang ZG: The role of vacuolar processing enzyme (VPE) from Nicotiana benthamiana in the elicitor-triggered hypersensitive response and stomatal closure. J Exp Bot 2010, 61:3799-3812.

81. Arnold TM, Schultz JC: Induced sink strength as a prerequisite for induced tannin biosynthesis in developing leaves of Populus. Oecologia 2002, 130:585-593.

82. Roitsch T, Gonzalez MC: Function and regulation of plant invertases: sweet sensations. Trends Plant Sci 2004, 9:606-613.

83. Murayama S, Handa $\mathrm{H}$ : Genes for alkaline/neutral invertase in rice: alkaline/neutral invertases are located in plant mitochondria and also in plastids. Planta 2007, 225:1193-1203.

84. Tetlow IJ, Morell MK, Emes MJ: Recent developments in understanding the regulation of starch metabolism in higher plants. J Exp Bot 2004, 55:2131-2145

85. Tiessen A, Hendriks JH, Stitt M, Branscheid A, Gibon Y, Farre EM, Geigenberger P: Starch synthesis in potato tubers is regulated by posttranslational redox modification of ADP-glucose pyrophosphorylase: a novel regulatory mechanism linking starch synthesis to the sucrose supply. Plant Cell 2002, 14:2191-2213

86. Tiessen A, Prescha K, Branscheid A, Palacios N, McKibbin R, Halford NG, Geigenberger P: Evidence that SNF1-related kinase and hexokinase are involved in separate sugar-signalling pathways modulating posttranslational redox activation of ADP-glucose pyrophosphorylase in potato tubers. Plant J 2003, 35:490-500.

87. Li J, Ezquer I, Bahaji A, Montero M, Ovecka M, Baroja-Fernandez E, Munoz FJ, Merida A, Almagro G, Hidalgo M, Sesma MT, Pozueta-Romero J: Microbial volatile-induced accumulation of exceptionally high levels of starch in Arabidopsis leaves is a process involving NTRC and starch synthase classes III and IV. Mol Plant Microbe Interact 2011, 24:1165-1178.

88. Szydlowski N, Ragel P, Raynaud S, Lucas MM, Roldan I, Montero M, Munoz FJ, Ovecka M, Bahaji A, Planchot V, Pozueta-Romero J, D'Hulst C, Merida A: Starch granule initiation in Arabidopsis requires the presence of either class IV or class III starch synthases. Plant Cell 2009, 21:2443-2457.

89. Kossmann J, Lloyd J: Understanding and influencing starch biochemistry Crit Rev Biochem Mol 2000, 35:141-196.

90. Chen S, Li XQ, Zhao A, Wang L, Li X, Shi Q, Chen M, Guo J, Zhang J, Qi D, Liu G: Genes and pathways induced in early response to defoliation in rice seedlings. Curr Issues Mol Biol 2009, 11:81-100.

91. Fang XW, Li YB, Xu DH, Yang XM, Wang G: Activities of starch hydrolytic enzymes and starch mobilization in roots of Caragana korshinskii following above-ground partial shoot removal. Trees-Struct Funct 2007, 21:93-100. 
92. Gallagher JA, Volenec JJ, Turner LB, Pollock CJ: Starch hydrolytic enzyme activities following defoliation of white clover. Crop Sci 1997, 37:1812-1818

93. Schwachtje J, Minchin PEH, Jahnke S, van Dongen JT, Schittko U, Baldwin IT: SNF1-related kinases allow plants to tolerate herbivory by allocating carbon to roots. Proc Natl Acad Sci U S A 2006, 103:12935-12940.

94. Sauer N: Molecular physiology of higher plant sucrose transporters. FEBS Lett 2007, 581:2309-2317.

95. Berthier A, Desclos M, Amiard V, Morvan-Bertrand A, Demmig-Adams B, Adams WW, Turgeon R, Prud'homme MP, Noiraud-Romy N: Activation of sucrose transport in defoliated Lolium perenne L.: an example of apoplastic phloem loading plasticity. Plant Cell Physiol 2009, 50:1329-1344.

96. Meyer S, Lauterbach C, Niedermeier M, Barth I, Sjolund RD, Sauer N: Wounding enhances expression of AtSUC3, a sucrose transporter from Arabidopsis sieve elements and sink tissues. Plant Physiol 2004, 134:684-693.

97. Kubis SE, Pike MJ, Everett CJ, Hill LM, Rawsthorne S: The import of phosphoenolpyruvate by plastids from developing embryos of oilseed rape, Brassica napus (L.), and its potential as a substrate for fatty acid synthesis. J Exp Bot 2004, 55:1455-1462.

98. Prabhakar V, Lottgert T, Geimer S, Dormann P, Kruger S, Vijayakumar V, Schreiber L, Gobel C, Feussner K, Feussner I, Marin K, Staehr P, Bell K, Flugge UI, Hausler RE: Phosphoenolpyruvate provision to plastids is essential for gametophyte and sporophyte development in Arabidopsis thaliana. Plant Cell 2010, 22:2594-2617.

99. Flugge Ul, Hausler RE, Ludewig F, Gierth M: The role of transporters in supplying energy to plant plastids. J Exp Bot 2011, 62:2381-2392.

100. Sánchez-Hernández C, Martínez-Gallardo N, Guerrero-Rangel A, ValdésRodríguez S, Délano-Frier J: Trypsin and a-amylase inhibitors are differentially induced in leaves of amaranth (Amaranthus hypochondriacus) in response to biotic and abiotic stress. Physiol Plant 2004, 122:254-264

101. Babst BA, Ferrieri RA, Gray DW, Lerdau M, Schlyer DJ, Schueller M, Thorpe MR, Orians CM: Jasmonic acid induces rapid changes in carbon transport and partitioning in Populus. New Phytol 2005, 167:63-72.

102. Baldwin IT: Methyl jasmonate-induced nicotine production in Nicotiana attenuata: inducing defenses in the field without wounding. Entomol Exp Appl 1996, 80:213-220.

103. Thaler JS, Stout MJ, Karban R, Duffey SS: Exogenous jasmonates simulate insect wounding in tomato plants (Lycopersicon esculentum) in the laboratory and field. J Chem Ecol 1996, 22:1767-1781.

104. Kerchev PI, Fenton B, Foyer $\mathrm{CH}$, Hancock RD: Plant responses to insect herbivory: interactions between photosynthesis, reactive oxygen species and hormonal signalling pathways. Plant Cell Environ 2012, 35:441-453.

105. Massange-Sánchez J: Análisis de la expresión y caracterización molecular del gen Ah24 inducido por daño mecánico, herbivoría y adición exógena de MeJA en plantas de Amaranthus hypochondriacus. MSC thesis.: Cinvestav-Unidad Irapuato, Departamento de Biotecnología y Bioquímica; 2011.

106. Babst BA, Ferrieri RA, Thorpe MR, Orians CM: Lymantria dispar herbivory induces rapid changes in carbon transport and partitioning in Populus nigra. Entomol Exp App/ 2008, 128:117-125.

107. Beardmore T, Wetzel S, Kalous M: Interactions of airborne methyl jasmonate with vegetative storage protein gene and protein accumulation and biomass partitioning in Populus plants. Can J Forest Res 2000, 30:1106-1113.

108. Cipollini D: Consequences of the overproduction of methyl jasmonate on seed production, tolerance to defoliation and competitive effect and response of Arabidopsis thaliana. New Phytol 2007, 173:146-153.

109. Halitschke R, Gase K, Hui DQ, Schmidt DD, Baldwin IT: Molecular interactions between the specialist herbivore Manduca sexta (Lepidoptera, Sphingidae) and its natural host Nicotiana attenuata. VI. Microarray analysis reveals that most herbivore-specific transcriptional changes are mediated by fatty acid-amino acid conjugates. Plant Physiol 2003, 131:1894-1902.

110. McCloud ES, Baldwin IT: Herbivory and caterpillar regurgitants amplify the wound-induced increases in jasmonic acid but not nicotine in Nicotiana sylvestris. Planta 1997, 203:430-435.

111. Steinbrenner AD, Gomez S, Osorio S, Fernie AR, Orians CM: Herbivoreinduced changes in tomato (Solanum lycopersicum) primary metabolism: a whole plant perspective. J Chem Ecol 2011, 37:1294-1303.
112. Walling LL: The myriad plant responses to herbivores. J Plant Growth Regul 2000, 19:195-216.

113. Gepstein S, Sabehi G, Carp MJ, Hajouj T, Nesher MFO, Yariv I, Dor C, Bassani M: Large-scale identification of leaf senescence-associated genes. Plant $J$ 2003, 36:629-642.

114. Livak KJ, Schmittgen TD: Analysis of relative gene expression data using real-time quantitative PCR and the $2^{-\Delta \Delta \mathrm{Ct}}$ method. Methods 2001, 25:402-408

115. Roitsch T, Bittner M, Godt DE: Induction of apoplastic invertase of Chenopodium rubrum by D-glucose and a glucose analog and tissuespecific expression suggest a role in sink-source regulation. Plant Physiol 1995, 108:285-294.

116. Murray MG, Thompson WF: Rapid isolation of high molecular-weight plant DNA. Nucleic Acids Res 1980, 8:4321-4325.

117. Altschul SF, Gish W, Miller W, Myers EW, Lipman DJ: Basic local alignment search tool. J Mol Biol 1990, 215:403-410.

118. Teska JD, Coyne SR, Ezzel LJW, Allan CM, Redus SL: Identification of Bacillus anthracis using gas chromatographic analysis of cellular fatty acids and a commercially available database. Agilent Technologies Inc 2003, 1-5.

119. Wright DP, Scholes JD, Read DJ: Effects of VA mycorrhizal colonization on photosynthesis and biomass production of Trifolium repens L. Plant Cell Environ 1998, 21:209-216.

120. Scholes JD, Lee PJ, Horton P, Lewis DH: Invertase: understanding changes in the photosynthetic and carbohydrate metabolism of barley leaves infected with powdery mildew. New Phytol 1994, 126:213-222.

121. Bernfeld P: Amylases, a and $\beta$. Method Enzymol 1955, 1:149-158.

doi:10.1186/1471-2229-12-163

Cite this article as: Castrillón-Arbeláez et al:: Metabolic and enzymatic changes associated with carbon mobilization, utilization and replenishment triggered in grain amaranth (Amaranthus cruentus) in response to partial defoliation by mechanical injury or insect herbivory. BMC Plant Biology 2012 12:163.

\section{Submit your next manuscript to BioMed Central and take full advantage of:}

- Convenient online submission

- Thorough peer review

- No space constraints or color figure charges

- Immediate publication on acceptance

- Inclusion in PubMed, CAS, Scopus and Google Scholar

- Research which is freely available for redistribution 